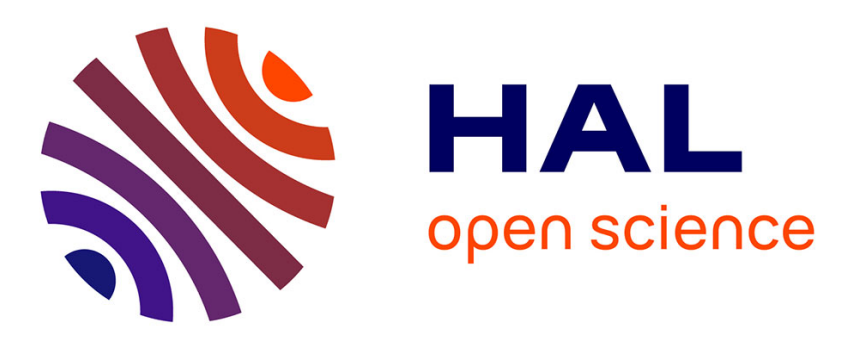

\title{
Identification of chemical species created during $\gamma$-irradiation of antioxidant used in polyethylene and polyethylene- co -vinyl acetate multilayer film
}

Samuel Dorey, Fanny Gaston, Nina Girard-Perier, Nathalie Dupuy, Sylvain R.A. Marque, Magali Barbaroux, Gérard Audran

\section{To cite this version:}

Samuel Dorey, Fanny Gaston, Nina Girard-Perier, Nathalie Dupuy, Sylvain R.A. Marque, et al.. Identification of chemical species created during $\gamma$-irradiation of antioxidant used in polyethylene and polyethylene- co -vinyl acetate multilayer film. Journal of Applied Polymer Science, 2020, pp.49336. 10.1002/app.49336 . hal-02617000

\section{HAL Id: hal-02617000 https://hal.science/hal-02617000}

Submitted on 25 May 2020

HAL is a multi-disciplinary open access archive for the deposit and dissemination of scientific research documents, whether they are published or not. The documents may come from teaching and research institutions in France or abroad, or from public or private research centers.
L'archive ouverte pluridisciplinaire HAL, est destinée au dépôt et à la diffusion de documents scientifiques de niveau recherche, publiés ou non, émanant des établissements d'enseignement et de recherche français ou étrangers, des laboratoires publics ou privés. 


\title{
Identification of chemical species created during $\gamma$-irradiation of antioxidant used in polyethylene and polyethylene-co-vinyl acetate multilayer film
}

\author{
Samuel Dorey ${ }^{1} \quad$ | Fanny Gaston ${ }^{1} \quad$ Nina Girard-Perier ${ }^{1,2,3}$ | \\ Nathalie Dupuy $^{2}$ | Sylvain R.A. Marque ${ }^{3}$ | Magali Barbaroux ${ }^{1}$ | Gérard Audran ${ }^{3}$
}

${ }^{1}$ Sartorius Stedim FMT S.A.S, Z.I. Les Paluds, Aubagne Cedex, France

${ }^{2}$ Aix Marseille Univ, CNRS, IRD, Avignon Université, Marseille, France

${ }^{3}$ Aix Marseille Univ, CNRS, ICR, case 551, Marseille cedex, France

Samuel Dorey, Sartorius Stedim FMT S.A.S, Z.I. Les Paluds, Avenue de Jouques CS91051, 13781 Aubagne Cedex, France. Email: samuel.dorey@sartorius.com Sylvain R. A. Marque,Aix Marseille Univ, CNRS, ICR, case 551, 13397 Marseille cedex 20, France.

Email: sylvain.marque@univ-amu.fr

\begin{abstract}
With the increasing use of $\gamma$-irradiated containers made of multilayer polymeric flexible films for food and biopharmaceutical applications, the possible migration of degradation products of the polymers and their additives is becoming a topic of concern. This article aims at highly reliably identifying the degradation products generated after gamma irradiation and their origin to later on assess their potential harmfulness in single-use containers. In this study, GC-MS is used to identify by-products created by $\gamma$-irradiation of primary and secondary antioxidants usually present in polyolefin-based biotechnological single-use materials and to confirm identification relevancy based on the literature survey or standard when available. Degradation pathways are proposed to account for the formation of by-products identified during the study and to list intermediates and other by-products present in too small amounts to be detected and identified accurately in all extractable studies.
\end{abstract}

\section{KEYW O R D S}

biocompatibility, copolymers, packaging, polyolefins

\section{1 | INTRODUCTION}

Nowadays, presterilized single-use containers are commonly used in the biopharmaceutical and biotechnology industries to replace stainless steel tanks. The use of such bags, made of multilayer polymeric films and mostly $\gamma$ sterilized, ${ }^{[1,2]}$ reduces the need for capital investment, shortens the drug manufacturing and industrialization process times, and avoid any risk of cross contamination that may be due to the inefficient cleaning of reusable tanks in GMP facilities. ${ }^{[3,4]}$ Authorities require the industry to demonstrate that chemicals that would migrate from production systems such as single-use containers do not alter the safety, efficiency, potency, or purity of drug products. $^{[5,6]}$ In pharmaceutical applications, it is mandatory to demonstrate the suitability of a contact material for its intended use, ${ }^{[7]}$ in contrast to the food industry where standardized extraction conditions are defined by regulatory authorities in guidelines (FDA Guidance to Industry $^{[8]}$ ) and/or regulations, ${ }^{[9,10]}$ for interaction studies. Various initiatives in industry organizations (BPSA, PDA, BPOG, PQRI, ASME BPE), ${ }^{[11-14]}$ standards organizations and regulatory authorities (USP, ASTM, EU Directive, UK Statutory Instrument, FDA $)^{[8,9,15-17]}$ directly work on the final component without necessarily anticipating the release of harmful or process detrimental compounds. ${ }^{[18]}$ Despite the attention, many researchers have paid to the understanding of the chemistry of the polymers and their appropriate additives, some issues have been highlighted empirically 
when using plastic packing material either in biotechnology applications ${ }^{[18]}$ or in food stuffs ${ }^{[19-22]}$ and are worth being anticipated as much as it could be.

Most packaging materials are coextruded multilayer structures based on polyolefin materials such as polyethylene (PE), polypropylene (PP), and ethylene-vinyl acetate (EVA). Related monographies are available in the European Pharmacopeia (E.P.), ${ }^{[23]}$ for instance. These materials could not be used without addition of additives, antioxidants or slipping agents, dedicated to protect the polymeric chains during the film extrusion process against oxidation or depolymerization processes or chain shortening events. Very few polymers can be used without additives. ${ }^{[24]}$ A typical stabilization package for polyolefin will usually consist of a phenol, a phosphite, and an antacid/slip agent.

The effects of ionizing radiation on polymers have been widely investigated ${ }^{[25-38]}$ and many additives will thus degrade into by-products, which contributes to discoloration. $^{[39,40]}$ The migration of volatile compounds in multilayer food packaging after gamma irradiation has also been studied ${ }^{[41-49]}$ and highlighted. It has been proven that pristine additives and their by-products are capable of migrating from the matrix toward the solution contained in the bag, potentially altering the product quality, safety, and/or efficiency. ${ }^{[50]}$ Computation could also be used to predict the degradation of polymers. ${ }^{[51]}$

Material degradation always implies the generation of radicals, which are often scavenged by $\mathrm{O}_{2}$ to generate second- or third-generation radicals quenched by the presence of additives. A typical chain-breaking activity due to the scavenging of ROO and $\mathrm{RO}^{\circ}$ radicals is involved, together with a specific reactivity with oxygen and hydroperoxides.

Primary antioxidants (AOs) (e.g., 1, 2, and 3, see Table 1) work by donating hydrogen atoms to radicals (often RO', ROO'), thereby interrupting the autoxidation process (Scheme 1). They are mainly used to increase the long-term thermal stability of various coatings, plastics, adhesives, and sealants. Secondary antioxidants (e.g., 4, see Table 1) decompose (hydro)peroxides (ROOH/ROOR) generated during the autoxidation process and extend the performance of primary AOs through synergistic effects (Scheme 1).

For instance, 2,6-di-tert-butyl-hydroxytoluene (BHT, E-321) is a synthetic phenolic antioxidant, which has been widely used as an additive in the food, cosmetic, and plastic industries for the past 70 years. ${ }^{[52]}$ In recent years, special attention has been paid to 14 known degradation products occurring in such proportion as to be

TA B LE 1 List of the additives studied and their structures

\begin{tabular}{|c|c|c|c|}
\hline Additive name & Function & Structure & Purity (\%) \\
\hline $\begin{array}{l}\text { 1: BHT (2,6-di-tert-butyl- } p \text {-cresol) } \\
\text { CAS 128-37-0 }\end{array}$ & Primary antioxidant & & $\geq 99$ \\
\hline $\begin{array}{l}\text { 2: Octadecyl } \\
\text { 3-(3,5-di-tert-butyl-4-hydroxyphenyl) } \\
\text { propionate } \\
\text { CAS 2082-79-3 }\end{array}$ & Primary antioxidant & & 99 \\
\hline $\begin{array}{l}\text { 3: Pentaerythritol tetrakis } \\
\text { (3-(3,5-di-tert-butyl-4-hydroxyphenyl) } \\
\text { propionate) } \\
\text { CAS } 6683-19-8\end{array}$ & Primary antioxidant & & 98 \\
\hline $\begin{array}{l}\text { 4: Tris (2,4-di-tert-butylphenyl) phosphite } \\
\text { CAS 31570-04 }\end{array}$ & Secondary antioxidant & & 98 \\
\hline
\end{tabular}


SCHEME 1 General primary AO (hindered phenol) and secondary AO (phosphitebased antioxidant) reaction scheme [Color figure can be viewed at wileyonlinelibrary.com]

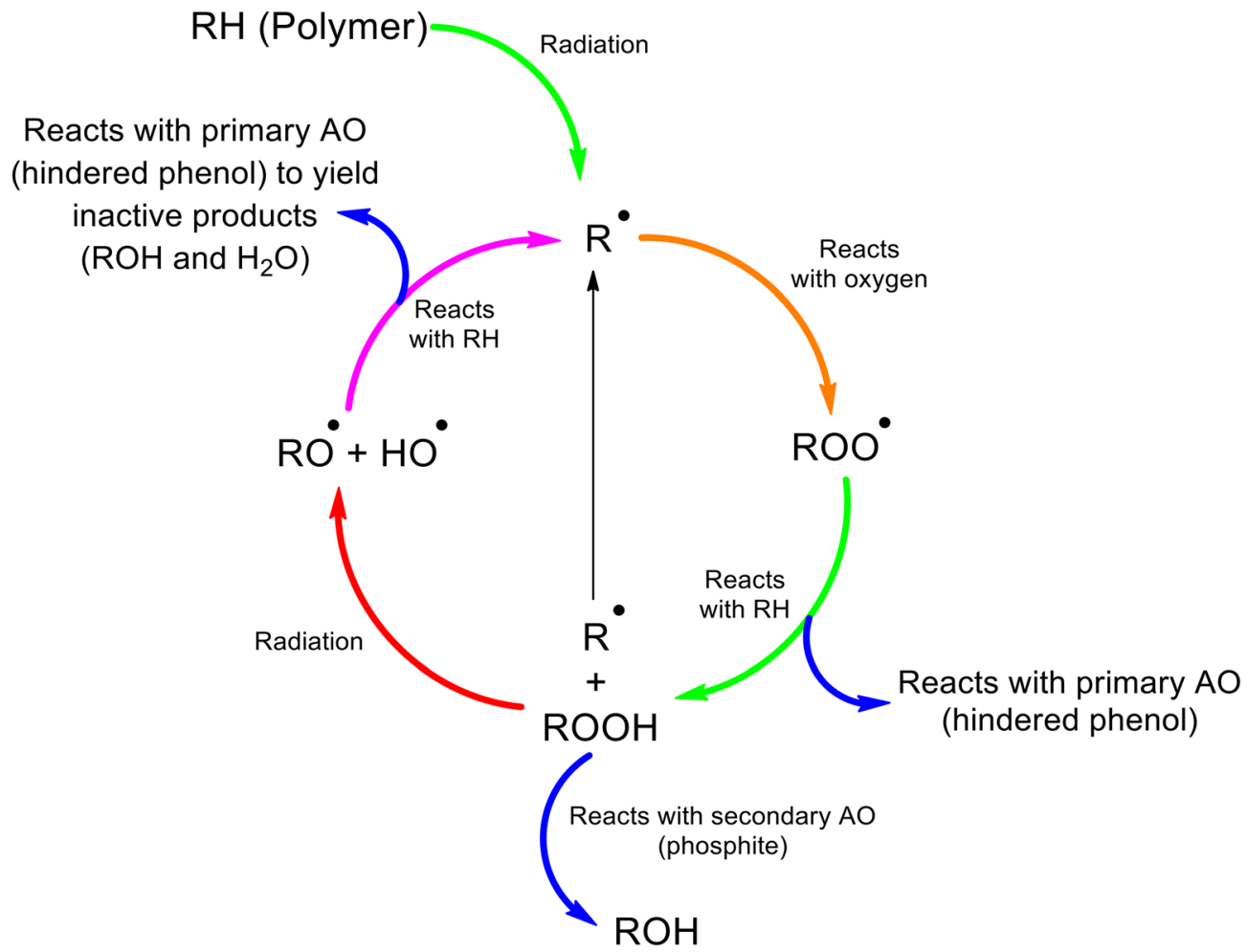

detectable in food simulants, for instance. ${ }^{[53,54]}$ Other by-products are not detectable in such experimental conditions and require another approach and assay to be detected. As the accumulation of apolar organic compounds in aqueous solutions will not reach concentrations that could be easily detected in interaction studies, mimicking biopharmaceutical applications or foodstuffs may last up to several weeks, months or years. The velocity for reaching the maximum or equilibrium concentrations of the extractables depends on the diffusion process and on the diffusion-influencing parameters (i.e., time, temperature, and specimen geometry) in the polymer. ${ }^{[55]}$ This urged us to work directly on the neat antioxidant by-products having a partition coefficient not so in disfavor of their accumulation in aqueous solution, that is to say, mostly $<500-700 \mathrm{amu}$, which makes them detectable by gas chromatography coupled with mass spectrometry. Defining a comprehensive extractable profile of packaging materials requires the use of orthogonal state-of-the-art analytical methods and is beyond the scope of this study. ${ }^{[56]}$ Therefore, risk mitigation of extractable and leachable in food industry or biopharmaceutical applications requires a holistic understanding of the $\gamma$-irradiation effects on the AOs used in packaging materials. Degradation pathways are proposed first to account for the formation of the byproducts and second to highlight intermediates as well and all other stable compounds that could be generated in small quantities and that could migrate in particular circumstances into biopharmaceutical solutions or food simulants for anticipation. A comprehensive profile of four antioxidant by-products, prone to migrate in aqueous media, is thus established using a combination of experimental gas chromatography and mass spectrometry in a first step and then theoretical radical degradation pathways.

\section{2 | EXPERIMENTAL}

The classical $\gamma$-irradiation dose range used in the biopharmaceutical industries is between 25 and $45 \mathrm{kGy}$. ${ }^{[57]}$ In this study, the $\gamma$-irradiation doses investigated are up to $270 \mathrm{kGy}$, in order to exaggerate the $\gamma$-irradiation effect and to thus better emphasize and investigate the modifications induced by $\gamma$-rays.

Antioxidants 1-4 were selected in E.P. 3.1.13 in order to represent widely used primary sterically hindered phenolic AOs and secondary phosphite AOs. Additives 1-4 (Table 1) were purchased from Sigma-Aldrich (SaintQuentin Fallavier, France) and sterilized in the glass flask at room temperature using a ${ }^{60} \mathrm{Co} \gamma$-source providing a dose rate of $8-13 \mathrm{kGy} / \mathrm{h}$ - as given by Synergy Health Marseille, France, at $25( \pm 5), 50( \pm 5)$, and up $115( \pm 5)$ and $270( \pm 5) \mathrm{kGy}$. The doses at $115 \mathrm{kGy}$ and $270 \mathrm{kGy}$ were used to exaggerate the effect obtained at 25-45 kGy so that higher quantities were obtained and investigation was made easier. The quantification of the 
analytes was performed after $270 \mathrm{kGy}$ where peaks were more intense. The AOs were irradiated in the glass flask at room temperature using a ${ }^{60} \mathrm{Co} \gamma$-source that provided a dose rate of $8-13 \mathrm{kGy} / \mathrm{h}$-as given by Synergy Health Marseille, France. The AOs were gamma irradiated without any matrices to avoid matrix interferences and to gain in detection sensitivity in comparison with other studies using plastics involving these additives. ${ }^{[24,55]}$

Solutions of additives at $100 \mu \mathrm{g} / \mathrm{mL}$ were prepared in dichloromethane and spiked with an internal standard (2-fluorobiphenyl) at $20 \mu \mathrm{g} / \mathrm{mL}$ and subsequently injected in GC-MS. Solutions were prepared in duplicate and injections were done in triplicate. The stability of the antioxidants was monitored over time beforehand to verify that aging in solution did not induce degradation. The quantitation estimate for each detected extractable peak was obtained in comparison with the internal standard peak. The by-products thus identifiable by GC-MS may be prone to migrate easily from the material core to reach aqueous based biopharmaceutical solution. Heavier byproducts not detectable by GC-MS and surely detectable by LC-MS also coexist in the polymers, but their migration to the aqueous solution is therefore weak. ${ }^{[58-60]}$

Each solution was injected in GC (PerkinElmer Clarus 500C) coupled with a mass detector (PerkinElmer Clarus $500 \mathrm{~T}$ ) and equipped with a column (Elite 5MS (Methylpolysiloxane [5\% Phenyl]), $60 \mathrm{~m} \times 0.25 \mathrm{~mm} \times$ $0.25 \mu \mathrm{m})$. The detection was performed by mass spectroscopy in electronic impact mode $\left(70 \mathrm{eV}\right.$ at $\left.280^{\circ} \mathrm{C}\right)$. Samples $(1 \mu \mathrm{L})$ were injected in splitless mode. The mass detector was calibrated with octafluoronaphtalene at $100 \mathrm{pg} / \mu \mathrm{L}$, with mass accuracy at $68.9973,219.0012$, and $501.9502 \mathrm{~m} / \mathrm{z}$. The injector temperature was set at $250^{\circ} \mathrm{C}$ and the column temperature was set from $35^{\circ} \mathrm{C}$ to $300^{\circ} \mathrm{C}$. The carrier gas (flow) helium was set at $1 \mathrm{~mL} / \mathrm{min}$. The mass range was 35-700 m/z. The limit of detection was determined with butylated hydroxytoluene (BHT) at $\mathrm{S} / \mathrm{N} \geq 3$. The precision was evaluated with several injections of $1 \mu \mathrm{g} / \mathrm{mL}$ BHT, leading to a relative standard deviation (RSD) of $20 \%$. The spike recovery was in the range of $80-120 \%$. This method proved trustworthy in detecting all the potential degradation products possibly migrating in aqueous solutions. ${ }^{[61,62]}$

Tables 2-4 summarize all chemicals detected after GC-MS analysis of freshly irradiated 1-4. A comparison with nonirradiated samples is made likewise to prove that the degradation products are due to the irradiation and not to the analysis conditions. The starting point for the generation of these compounds is the generation of the phenoxyl radical (Scheme 2). Chemicals are primarily identified by matching their mass spectra against available commercial NIST ${ }^{[67]}$ and Wiley ${ }^{[68]}$ databases, and for a few cases conventional analysis of molecular and parent peaks are performed.
The radical or cationic species are not detected by GC-MS, their shelf life being too short. Species in too small amounts are not detectable by GC-MS. Moreover, the GC-MS method does not make it possible to detect high molecular weight molecules such as by-products of 3 .

\section{3 | RESULTS AND DISCUSSION}

\section{1 | General comments}

\subsection{1 | $\gamma$-irradiation}

Under $\gamma$-irradiation, the phenolic compounds can lead to several mechanisms, depending on the ionization (Scheme 2). The ionization potential (IP) ${ }^{[69]}$ provides information on the electron lability under $\gamma$-ray ionization. The mechanism (1) in Scheme 2 is the most likely (IP $~ 8.37 \mathrm{eV}$ ) to occur. The mechanisms (2) and (3) in Scheme 2 can also exist (IP $\sim 10.25 \mathrm{eV}$ and IP $\sim 8.82 \mathrm{eV}$, respectively) but are not the prevailing ones. Concerning the reaction of the ester part of 2 and 3 under $\gamma$-rays, the mechanism (4) in Scheme 2 is possible $\left(\mathrm{IP}_{\left(\mathrm{C}-\mathrm{O}-\mathrm{C}^{+}\right)}=9.70 \mathrm{eV}\right.$ and $\left.\mathrm{IP}_{\left(\mathrm{C}=\mathrm{O}^{+}\right)}=10.94 \mathrm{eV}\right)$. The reaction of the phosphite under $\gamma$-rays according to mechanism (5) is conceivable $\left(\operatorname{IP}\left({ }_{\text {C18H15O3P }}+\right)=8.80 \mathrm{eV}\right)$. Unfortunately, not all standards are available and only a semiquantitative analysis was possible. For better discussion, quantification was performed only at $270 \mathrm{kGy}$. However, in most cases, products detected at $270 \mathrm{kGy}$ are also detected at lower doses, supporting our approach. As for the few cases of compounds detected only at $270 \mathrm{kGy}$, they were detected at trace level (see Tables 2-4).

\subsection{2 | Description of antioxidant reaction scheme}

Hindered phenols such as 1,2 , and 3 act as free-radical scavengers and prevent or interrupt oxidation reactions. They trap peroxyl radicals efficiently. The key reaction is the formation of hydroperoxide by transfer of hydrogen from the phenolic moiety to the peroxyl radical and the formation of a phenoxyl radical according to the reaction described in Scheme 3.

The decomposition of powder hindered phenol such as 1-3 under gamma irradiation has not raised much interest. Nevertheless, as decomposition is performed under air atmosphere whatever the type of irradiation or oxidation process, alkyl peroxyl radicals as well as phenoxyl radicals are generated. Consequently, most species reported in Scheme 4 are expected to be observed. 
<smiles>[R]c1cc([R])c([O-])c([R])c1</smiles>

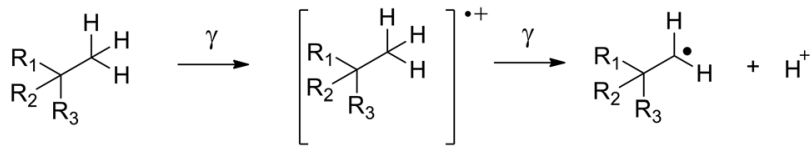

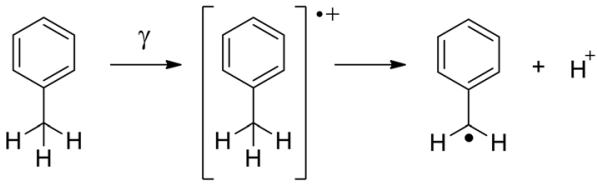<smiles>[R]OC(=O)CCc1cc([R])c(O)c([R])c1</smiles><smiles>[R]OC(=[OH+])CCc1cc([R])c(O)c([R])c1</smiles><smiles>[R]OC(=O)CCc1cc([R])c(O)c([R2])c1</smiles><smiles>[R]Oc1cc(CCC=O)cc([R])c1O</smiles><smiles>[111In]</smiles><smiles>CC(C)(C)c1ccc(OP(Oc2ccc(C(C)(C)C)cc2C(C)(C)C)Oc2ccc(C(C)(C)C)cc2C(C)(C)C)c(C(C)(C)C)c1</smiles>
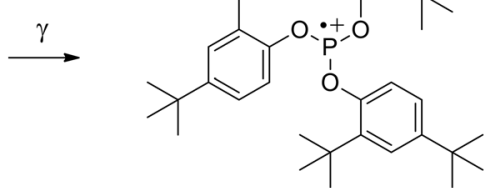<smiles>CC(C)(C)c1ccc(O[PH2+]Oc2ccc(C(C)(C)C)cc2C(C)(C)C)c(C(C)(C)C)c1</smiles><smiles>CC(C)(C)c1ccc([O-])c(C(C)(C)C)c1</smiles>

SCHEME 2 Phenolic compounds under $\gamma$-rays<smiles>[R]O[R]O[R]</smiles>

SCHEME 3 Formation of phenoxyl radicals

\section{2 | Degradation products of 1 (BHT) under gamma irradiation}

Table 2 summarizes all chemicals detected after GC-MS analysis of freshly irradiated BHT, showing that only phenylic and phenolic compounds are observed. Information about detected compound masses is given in Table 1 SI. The intermediate species depicted in the subsequent schemes to account for the formation of the detected compounds listed in Table 2 are numbered with the Greek letter $\boldsymbol{\alpha}$. It comes out that the main metabolites ${ }^{[53]}$ of the products of 1 (BHT) are detected.

Under gamma irradiation, BHT (1) affords either radical $\boldsymbol{\alpha 1}$, which reacts by disproportionation via its mesomeric form $\boldsymbol{\alpha 2}$ to yield 1 and 7 (Scheme 5) or radical $\boldsymbol{\alpha 5}$ ((2) in Scheme 2). The latter collapses into isobutene and $\boldsymbol{\alpha 6}$, which affords $\mathbf{6}$. The easiest way to generates 5 is a dehydration reaction in several steps which relies on the addition of $\mathrm{H} \bullet$, which is always generated to some extent under $\gamma$-ray, onto the hydroxyl group of 1 to generate radical $\boldsymbol{\alpha} 3$. The latter collapses to release water and aryl radical $\boldsymbol{\alpha 4}$, which abstracts an $\mathrm{H}$-atom to yield 5 (Scheme 6).

Products 9 and $\mathbf{1 0}$ are not discussed, as they are observed as traces and are likely released during gamma-irradiation of side products (Scheme 7). The generation of $\boldsymbol{\alpha} \mathbf{7}$ from $\mathbf{1}$ is supported by the formation 


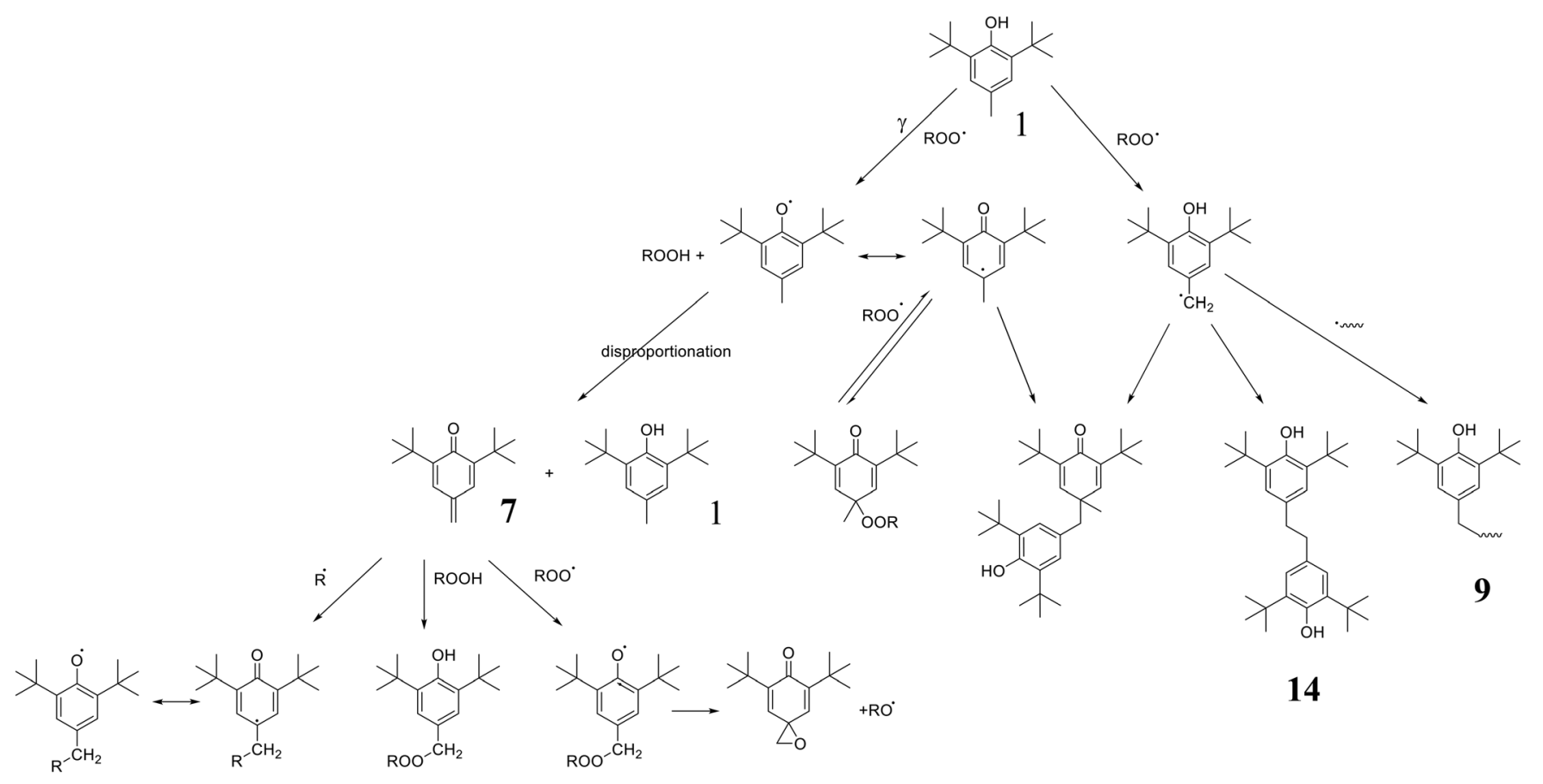

SCHEM E 4 Reaction of sterically partially hindered phenols and general reactions of quinone methides $7^{[70]}$

a)<smiles>Cc1cc(C(C)(C)C)c(O)c(C(C)(C)C)c1</smiles>

b)<smiles>Cc1cc(C(C)(C)C)c(O)c(C(C)(C)C)c1</smiles><smiles>Cc1cc(C(C)(C)C)c(O)c(C(C)(C)C)c1</smiles><smiles>CC(C)(C)c1cc([N+](=O)[O-])ccc1O</smiles><smiles>C=C(C)[CH2+]CCCCCCCC</smiles><smiles>Cc1cc(C(C)(C)C)c(O)c(C(C)(C)C)c1</smiles><smiles>CCCCCCCCCCCCCCCCCCC(C)(C)C</smiles><smiles>CC(C)(C)c1cc(I)cc(C(C)(C)C)c1O</smiles><smiles>C=C1C=C(C(C)(C)C)C(=O)C(C(C)(C)C)=C1</smiles><smiles>CCOc1c(C(C)(C)C)cc(Cl)cc1C(C)(C)C</smiles>

SCHEME 5 Mechanism proposal leading to (a) the formation of 6 (2-tert-butyl-4-methylphenol) and (b) disproportionation of the phenoxyl (or mesomeric cyclohexadienonyl)

of traces of $\mathbf{1 4}$ (dimerization) and $\mathbf{1 3}$ (coupling between $\alpha 6$ and $\alpha 7)$. The minor products ( 11 and 12$)$ and traces $(8,13$ and 14$)$ are accounted by a manifold based on the generation of $\alpha \mathbf{7}$. The small amount of $\mathbf{1 3}$ and $\mathbf{1 4}$ denotes that $\boldsymbol{\alpha} \boldsymbol{7}$ is quickly scavenged by $\mathrm{O}_{2}$ to generate peroxyl radical $\boldsymbol{\alpha} \mathbf{8}$. Through an oxidation reaction, it releases alkoxyl radical $\boldsymbol{\alpha 9}$, which affords $\mathbf{1 1}$ and $\mathbf{1 2}$ through a disproportionation process. However, the slightly larger amount of $\mathbf{1 1}$ than of $\mathbf{1 2}$ denotes the occurrence of another pathway for the generation of 11. That is, addition of peroxyl radical on 7 is possible to afford $\boldsymbol{\alpha 1 0}$, which is reduced into 11. Further oxidation of $\mathbf{1 1}$ and $\mathbf{1 2}$ into 8 is a very minor pathway, as 8 is observed as traces. 


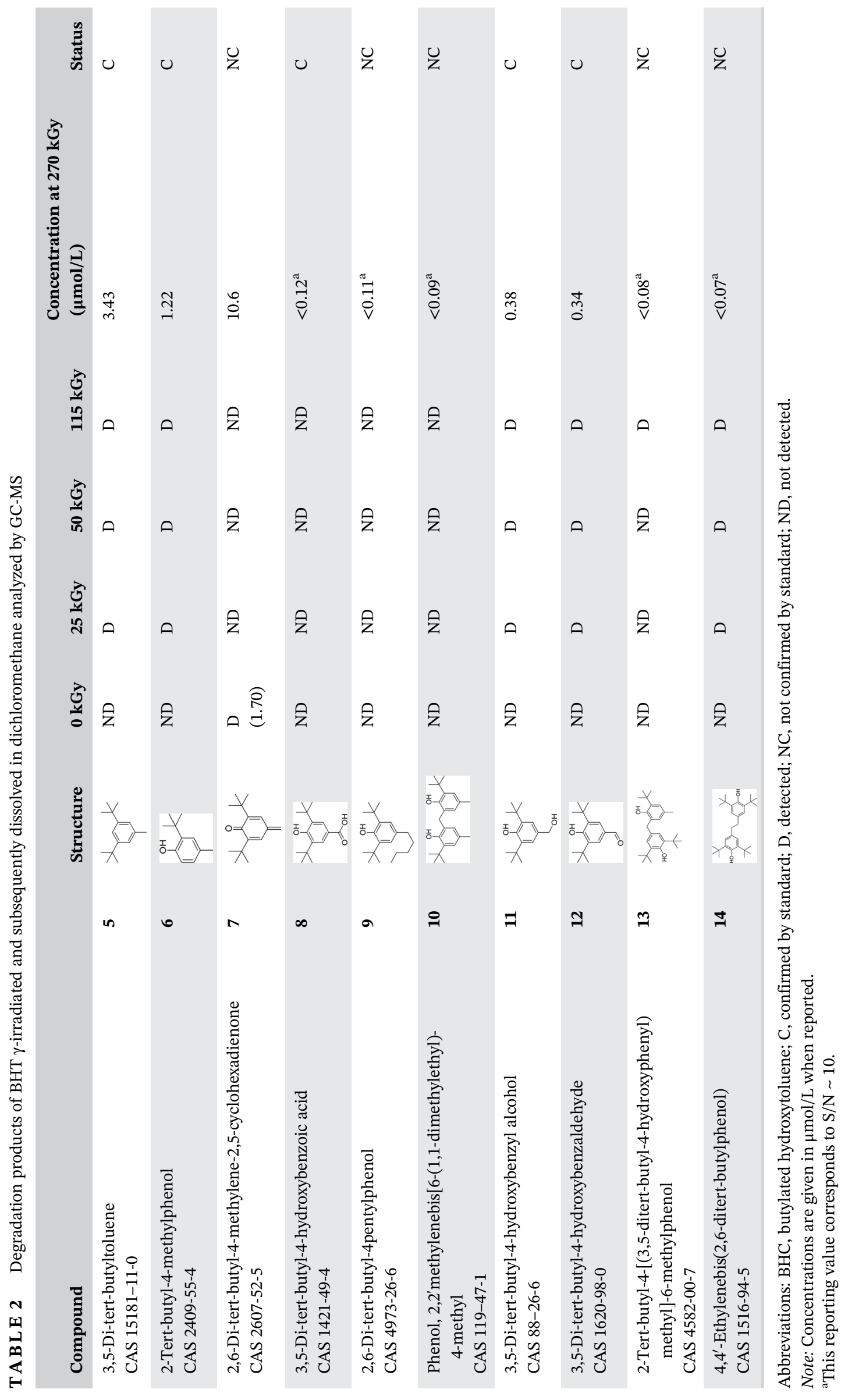




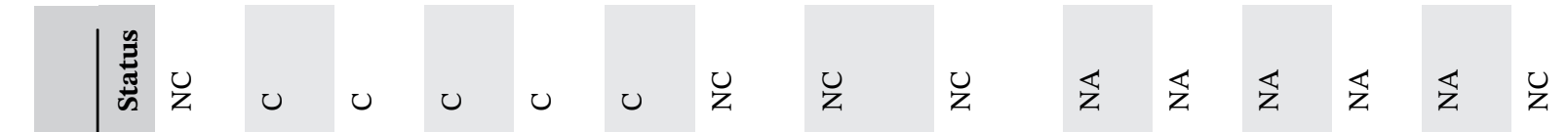

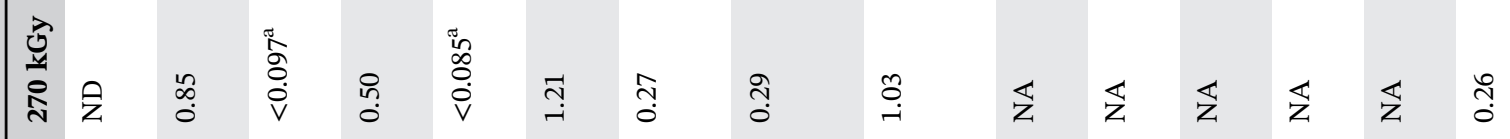
竞

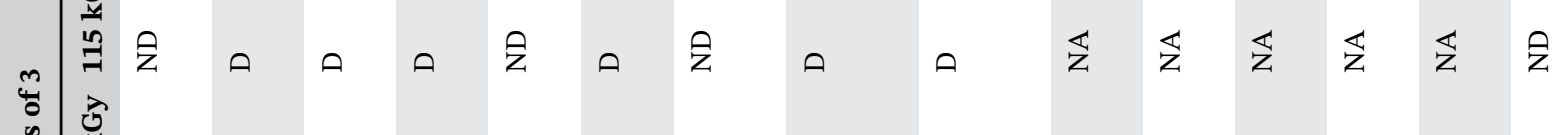

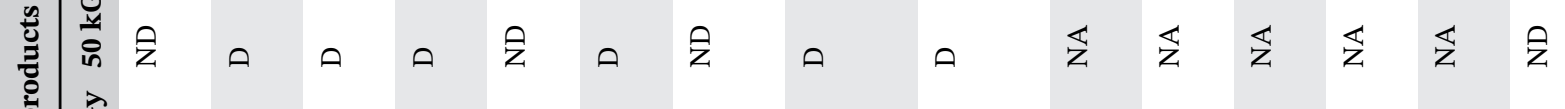

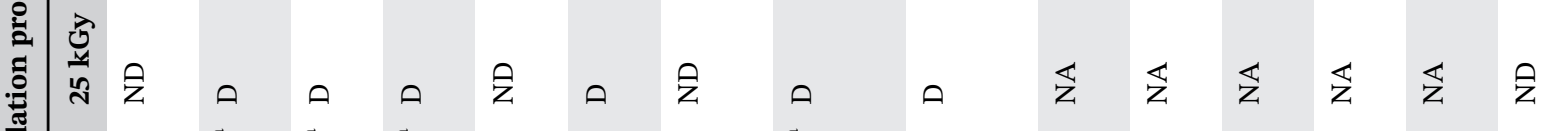

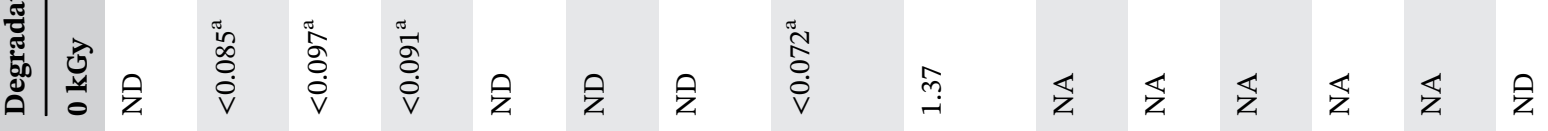

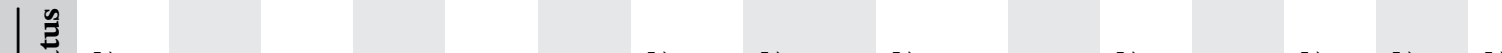

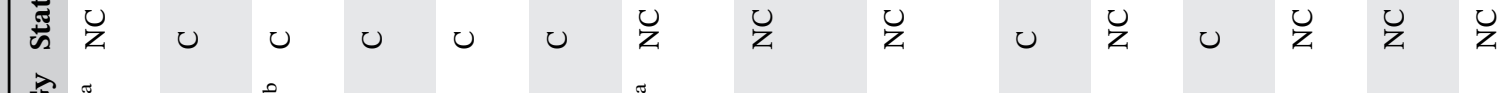

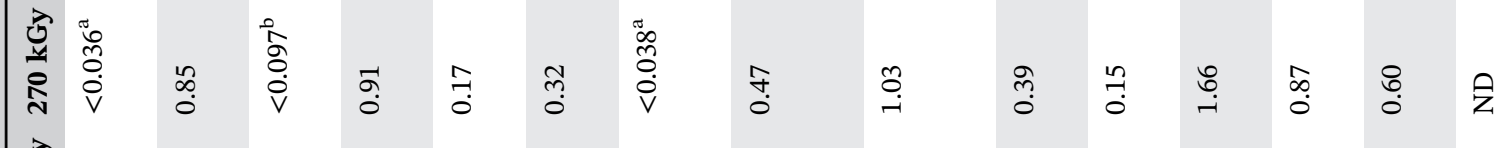

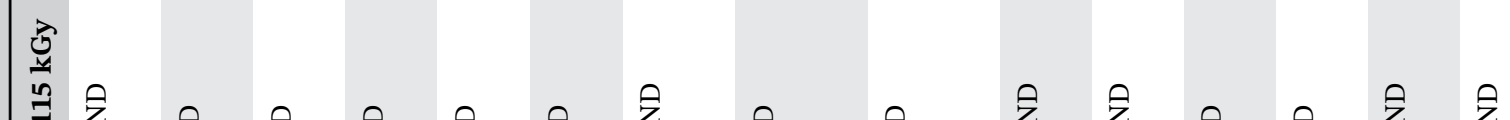

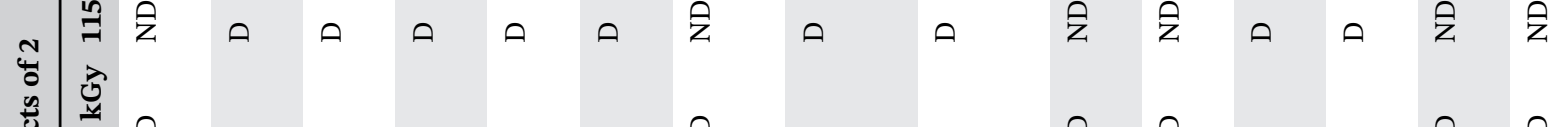

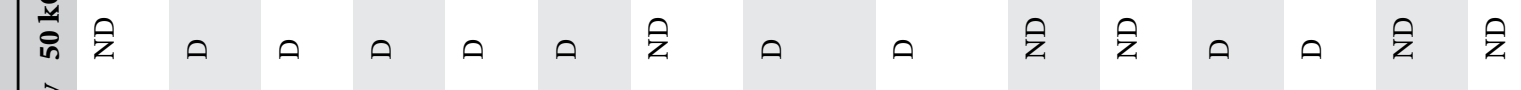

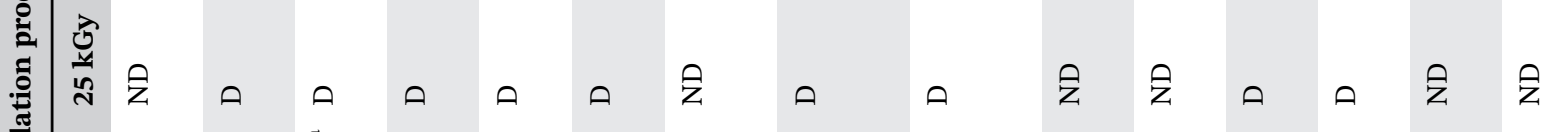

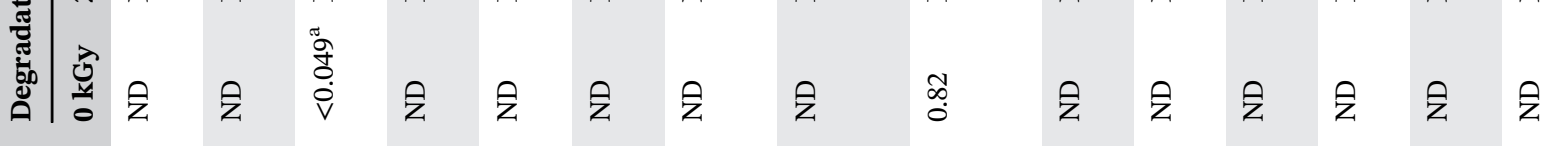

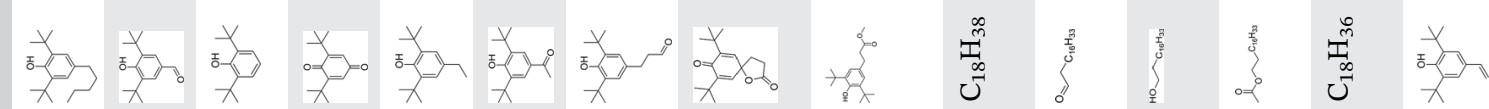

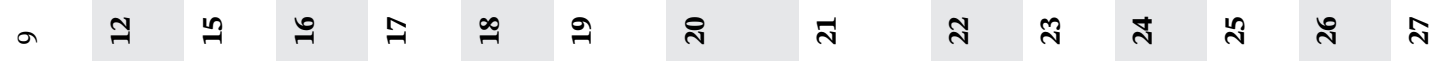

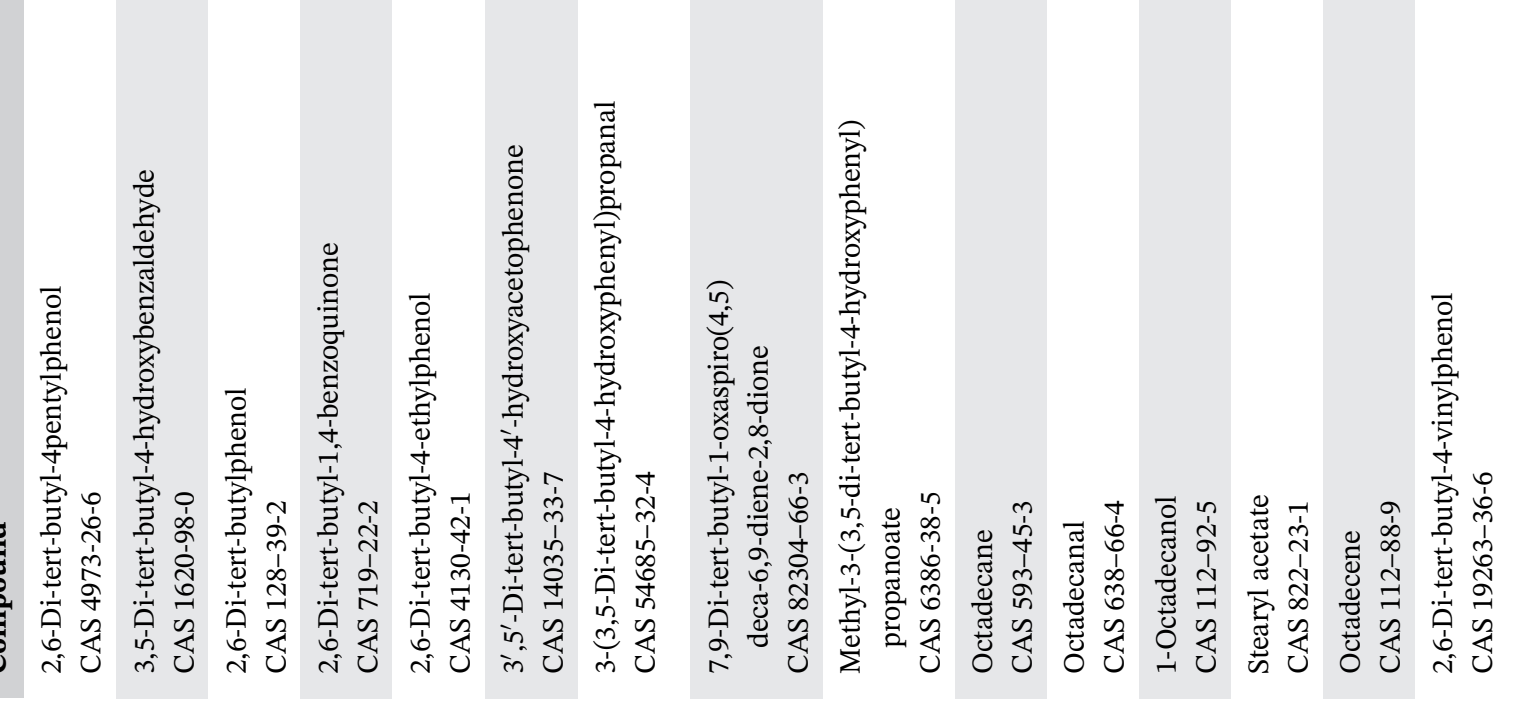




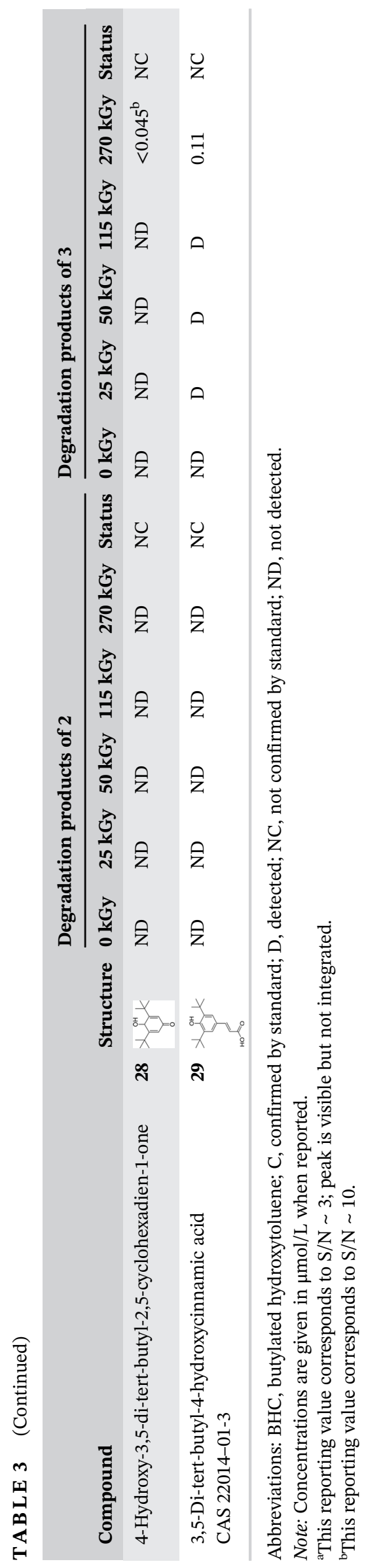

\section{3 | Degradation products of 2 (octadecyl 3-(3,5-di-tert-butyl- 4-hydroxyphenyl)propionate) and 3 (pentaerythritol tetrakis(3-(3,5-di-tert- butyl-4-hydroxyphenyl)propionate))}

Unlike BHT (1), molecule 2 carries an ester function at position para. As a consequence, besides the conventional chemistry of the phenolic moiety as observed for BHT, several new manifolds are observed: cinnamate manifold (Figure 1 and Scheme 8), ester manifold (Scheme 9), $\mathrm{O}_{2}$ manifold (Scheme 10), benzylic manifold (Scheme 11), acidic manifold (Scheme 12) in which several intermediates are implied. The formation of primary phenoxyl, quinone methide and products of molecular rearrangement and dimerization should be considered as a reason for the high efficiency of systems containing the 4-hydroxyphenylpropionate moiety. ${ }^{[71]}$ The latter is transformed into a cinnamate moiety (Figure 1). Table 3 summarizes all the chemicals detected after GC-MS analysis of freshly irradiated 2 and 3. Information about detected compound masses is given in Tables 2 SI and Table 3 SI. Intermediates used in Schemes 8-12 to describe the degradation of 2 are labeled with the Greek letter $\boldsymbol{\beta}$ and listed in Figure 2.

Importantly, most of the degradation products observed for 2 are also reported for 3 (which carries four ester moieties). Compounds 22-26 are not observed during the degradation of 3 because the structure of 3 is not suitable. However, manifolds described in Schemes 8-12 require the generation of parent compounds which cannot be detected in our case because of their high molecular weights. Some compounds such as 9, 15, 21 and 28 are not discussed, as they are detected at the level of traces or in the starting materials.

\subsection{1 | Cinnamate manifold}

The first step is the generation of phenoxyl radical $\boldsymbol{\beta} \mathbf{1}$ by gamma-irradiation (Scheme 8). The mesomeric form $\boldsymbol{\beta 2}$ reacts by fragmentation to afford 7 and alkyl radical $\boldsymbol{\beta 4}$, which abstracts an H-atom to yield 25. Molecule 7 is oxidized by ozone to yield $\mathbf{1 6}$ and formaldehyde/formic acid. As fragmentation (of $\boldsymbol{\beta 2}$ ) has some specific requirements and as 3 is more constrained than 2, fragmentation of $\boldsymbol{\beta 2}$ to afford 7 is less favored in 3 than in 2. Hence, $\mathbf{1 6}$ is obtained in higher quantity for $\mathbf{2}$ than for $\mathbf{3}$.

\subsection{2 | Ester manifold}

Obviously, the whole set of detected products cannot be represented by one single phenoxy radical alone. 
<smiles>CC(C)(C)c1cc(I)cc(C(C)(C)C)c1O</smiles>

1

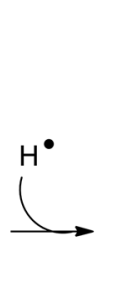

.<smiles>[CH][C+](O)=Cc1cc(C)cc(C(C)(C)C)c1C(C)(C)C</smiles>

$\alpha 3$<smiles>Cc1cc(C(C)(C)C)cc(C(C)(C)C)c1</smiles>

$\alpha 4$<smiles>Cc1cc(C(C)(C)C)cc(C(C)(C)C)c1</smiles>

5
SCHEME 6 Mechanism proposal leading to the formation of 5. " $\mathrm{H}$." for an $\mathrm{H}-$ atom provided by the surrounding

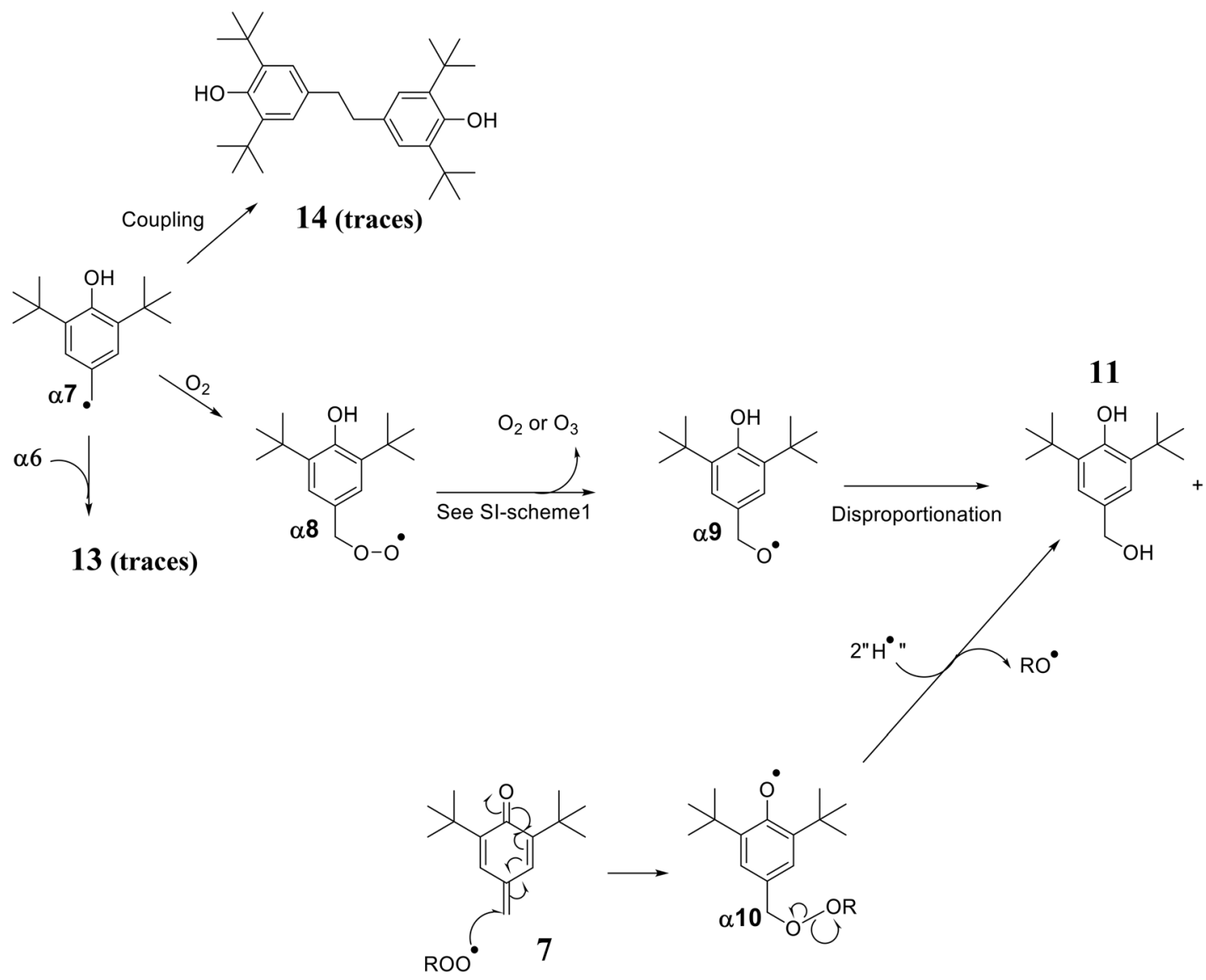

12<smiles>CC(C)(C)c1cc(C=O)cc(C(C)(C)C)c1O</smiles>

Oxidation<smiles>CC(C)(C)c1cc(C(=O)O)cc(C(C)(C)C)c1O</smiles>

8 (traces)

SCHEME 7 Mechanism proposal leading to the formation of 8, 11, 12, 13 and 14

Therefore, the generation of radical cations $\boldsymbol{\beta 5}$ and $\boldsymbol{\beta 6}$ on the ester moiety is envisioned, affording the manifold depicted in Scheme 9. Positively charged radicals $\boldsymbol{\beta 7}$, $\boldsymbol{\beta 1 1}$, and $\boldsymbol{\beta 2 3}$ are generated by intramolecular $1,4-\mathrm{H}$ transfer in $\boldsymbol{\beta 5}$ and $\boldsymbol{\beta 6}$. $\boldsymbol{\beta 1 7}$ is generated by intramolecular $1,5-\mathrm{H}$ transfer in $\boldsymbol{\beta 5}$. 1,5- $\mathrm{H}$ and 1,6- $\mathrm{H}$ transfers are disregarded for $\boldsymbol{\beta 6}$, as no corresponding products are observed whatever the chemistry assumed. By loss of protons, these charged radicals afford $\beta 8, \boldsymbol{\beta 1 2}$, and $\boldsymbol{\beta 1 8}$. Radical $\boldsymbol{\beta 8}$ either reacts with $\mathrm{O}_{2}$ (see benzylic radical manifoldScheme 11) or collapses into $\boldsymbol{\beta 9}$ and $\mathbf{2 7}$, which is further oxidized in $\mathbf{1 2}$ by ozone. As $\boldsymbol{\beta 9 H}$ is not observed, the decarboxylation of $\boldsymbol{\beta 9}$ is the main pathway to release $\boldsymbol{\beta 1 0}$,<smiles>[R]OC(=O)/C=C/c1cc(C(C)(C)C)c(O)c(C(C)(C)C)c1</smiles>

FIGURE 1 Cinnamate moiety

which decays likely through a self-termination reaction to afford 22 and 26. Interestingly, the occurrence of the generation of $\boldsymbol{\beta} 18$ is supported by its decomposition into 


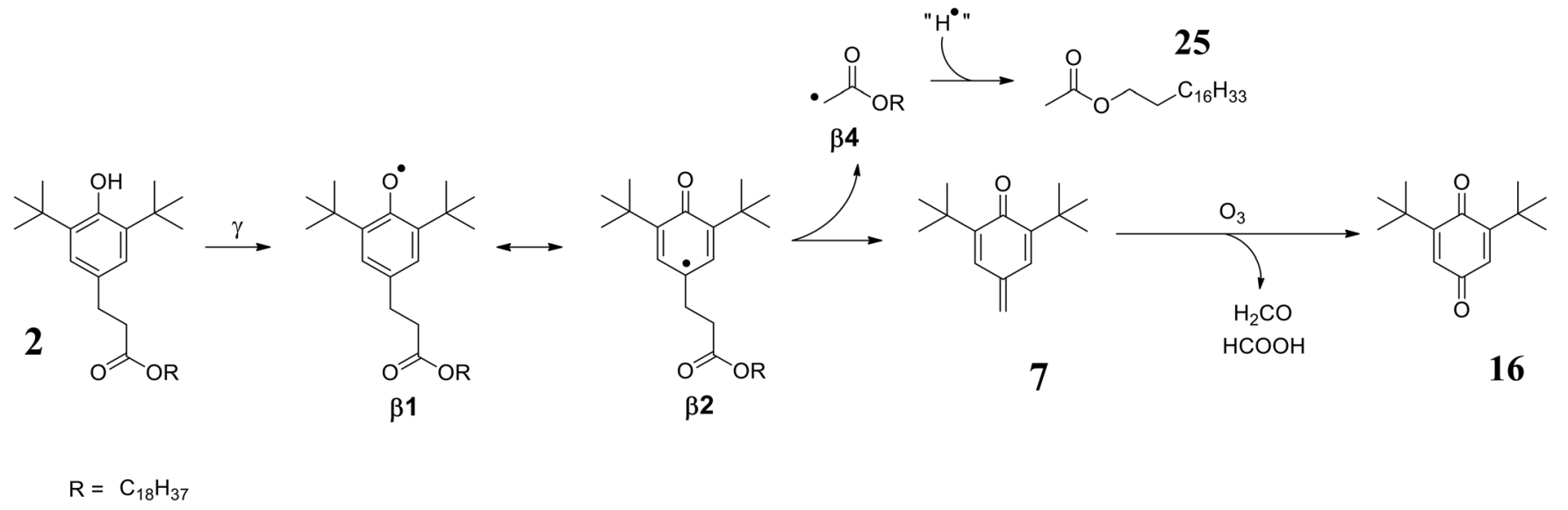

SCHEME 8 Cinnamate manifold for the generation of 25, 7 and 16

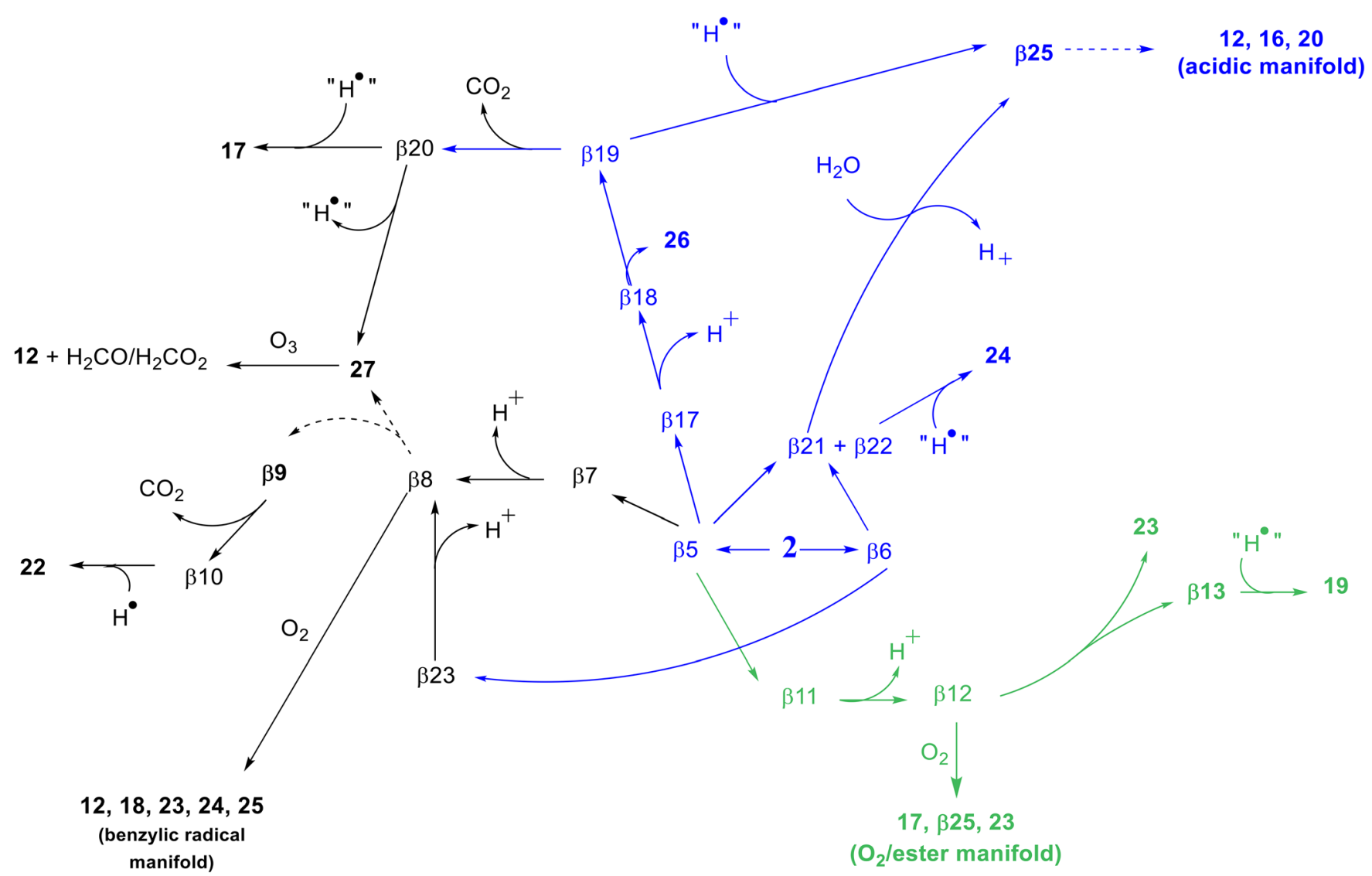

SCHEME 9 Ester manifold for the generation of 17, 12, 22, 26, 27, 23, 19, 24, 26. Intermediate compounds are listed in Figure 2 [Color figure can be viewed at wileyonlinelibrary.com]

26 (second pathway for its generation) and alkyl acyloxyl radical $\boldsymbol{\beta 1 9}$. The latter can either abstract an $\mathrm{H}$-atom to afford $\boldsymbol{\beta 2 5}$ or to decarboxylate to afford $\boldsymbol{\beta 2 0}$, which in turn abstracts an $\mathrm{H}$-atom to yield 17. Loss of $\mathrm{H}$ atom on the benzylic position in $\mathbf{\beta 2 0}$ might be assumed to afford 27, which is further oxidized in $\mathbf{1 2 . 1 7}$ is obtained in lower quantity for 3 than for 2 because the formation of $\boldsymbol{\beta 1 8}$ is not possible.
Radical $\boldsymbol{\beta 1 2}$ may either react with $\mathrm{O}_{2}$ to afford 17, $\boldsymbol{\beta 2 5}$ and 23 (see Scheme 10) or decompose in 23 and acyl radical $\beta 13$, which abstracts an $\mathrm{H}$-atom to yield 19. The number of ester moieties favors the generation of $\boldsymbol{\beta 1 1}$ and $\beta \mathbf{1 2}$ and hence the formation of 19. That is the reason why 19 is obtained in higher quantity for $\mathbf{3}$ than for $\mathbf{2}$.

Besides 1,4 or 1,5- $\mathrm{H}$ transfer events, radical cations $\boldsymbol{\beta 5}$ and $\boldsymbol{\beta} \mathbf{6}$ can collapse through a mesolysis event to afford 


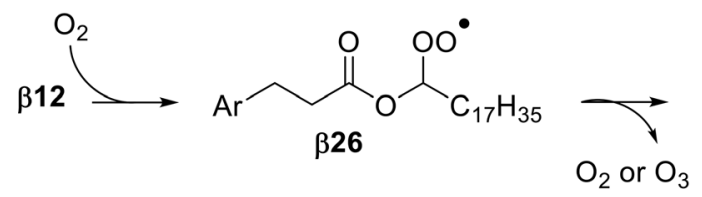

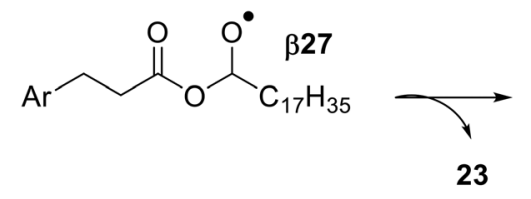<smiles>CC(C)CC(=O)C(C)C</smiles><smiles>O=C(O)CC[Te]</smiles>

Acidic manifold

SCHEME $10 \mathrm{O}_{2}$ manifold for the generation of 23 and 17. Intermediate compounds are listed in Figure 2

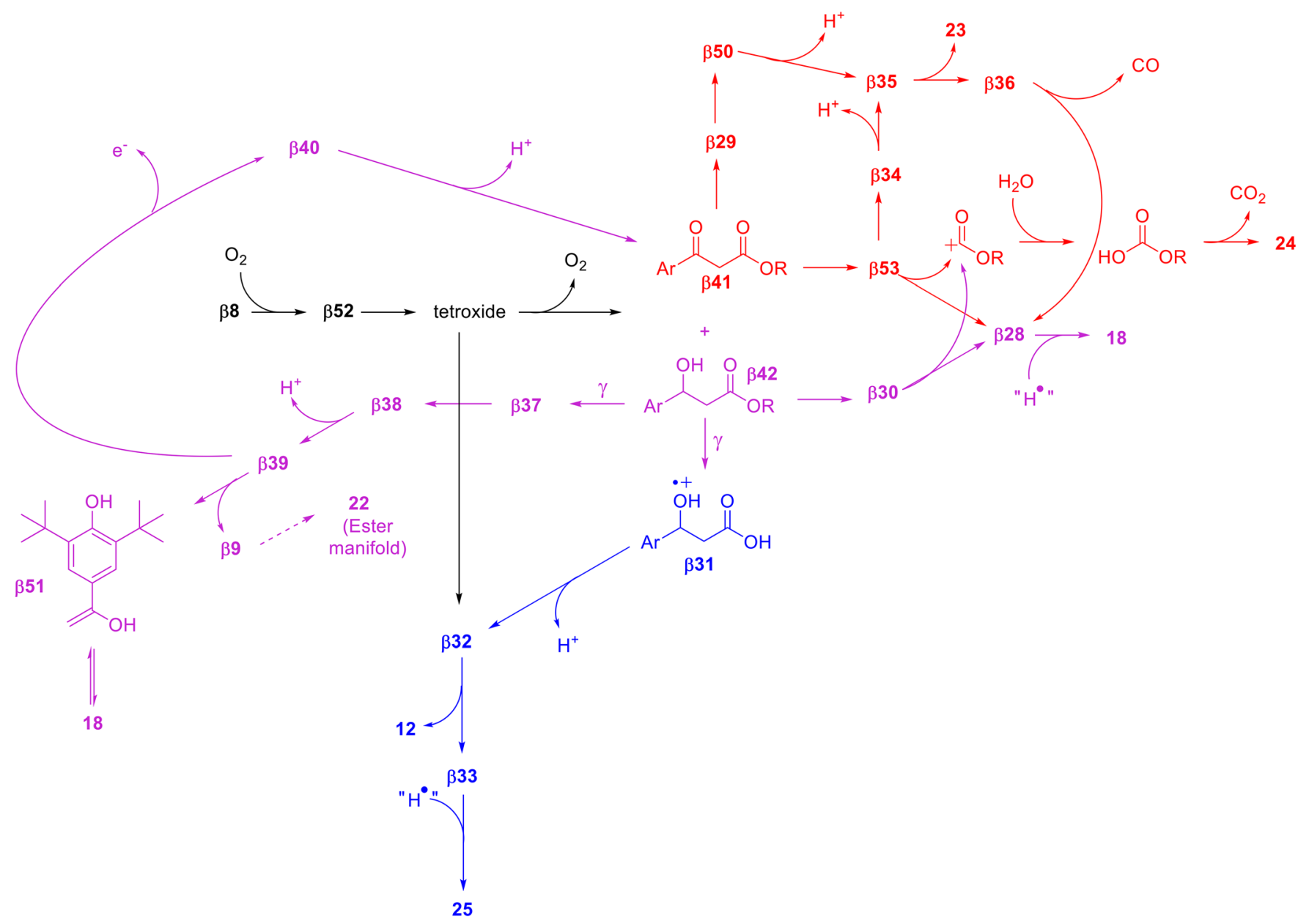

SCHE M E 11 Benzylic radical/ $\mathrm{O}_{2}$ manifold for the generation of 12, 25, 23, 18, 24. Intermediate compounds are listed in Figure 2 [Color figure can be viewed at wileyonlinelibrary.com]

acylium $\boldsymbol{\beta 2 1}$ and alkoxyl radical $\boldsymbol{\beta 2 2}$. Cation $\boldsymbol{\beta 2 1}$ reacts spontaneously with water to release a proton and to yield 及25, which in turn leads to 12, 16 and 20 through a sequence of events (Scheme 12). On the other hand, $\boldsymbol{\beta 2 2}$ reacts by $\mathrm{H}$-abstraction to afford $\mathbf{2 4}$.

The presence of $\mathbf{2 0}$ formed only from $\boldsymbol{\beta 2 5}$ points to the occurrence of the acidic manifold. However, as $\mathbf{1 2}$ and $\mathbf{1 6}$ are already detected in Schemes 8 and 9, no discussion on the importance of this manifold can be performed. Moreover, $\boldsymbol{\beta 2 5}$ points to the occurrence of pathways-in blue and green in Scheme 9.

The larger amount of $\mathbf{2 0}$ observed in 2 than in 3 is not surprising, as the intermediate $\boldsymbol{\beta 2 5}$ (required for the formation of 20) is partly formed via the degradation of $\boldsymbol{\beta 1 2}$. 


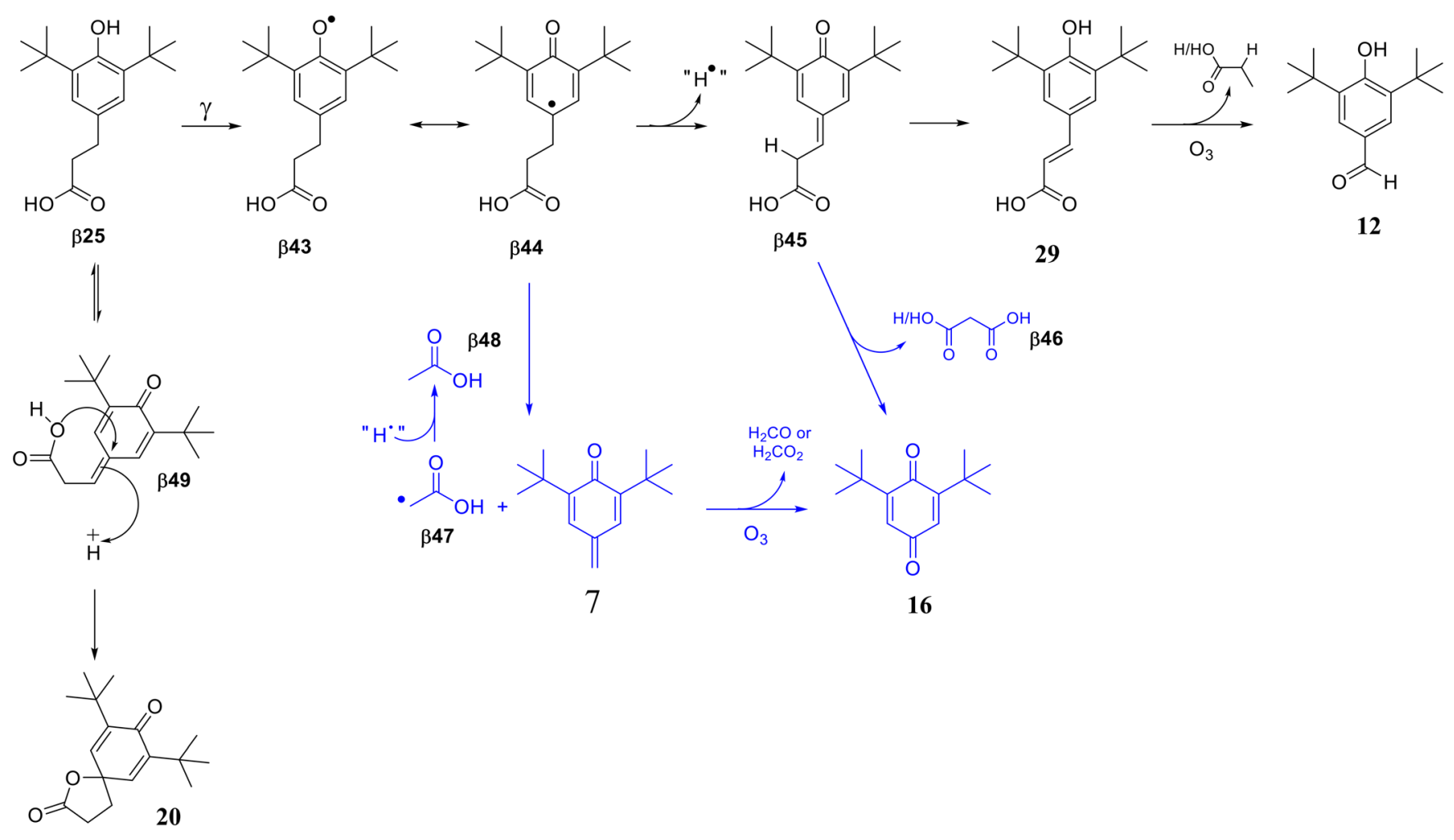

SCHEME 12 Acidic manifold for the formation of 7, 12, 16, 20 and 29 [Color figure can be viewed at wileyonlinelibrary.com]

The larger amount of $\mathbf{2 7}$ in 3 than in 2 is likely due to the occurrence of the degradation of $\boldsymbol{\beta 8}$-type intermediates, which does not occur for 2 .

\subsection{3 $\quad \mathrm{O}_{2}$ /ester manifold}

All alkyls radicals may react with $\mathrm{O}_{2}$ to generate alkyl peroxyl radicals, which either combine into tetroxides to further collapse into alkoxy radicals and $\mathrm{O}_{2}$ or react with $\mathrm{O}_{2}$ to generate ozone and alkoxyl radicals. The latter then collapse into alkyl radicals or ketone/aldehyde and alcohols. Here, only the pathways affording the products reported in Table 2 are envisioned. Hence, $\boldsymbol{\beta 1 2}$ reacts with $\mathrm{O}_{2}$ to afford peroxyl radical $\boldsymbol{\beta 2 6}$, which is degraded into $\mathbf{\beta 2 7}$, which decomposes into $\mathbf{2 3}$ and 及19. The latter either abstracts an $\mathrm{H}$ atom to afford $\boldsymbol{\beta 2 5}$ or decarboxylates to afford $\boldsymbol{\beta 2 0}$, which yields $\mathbf{1 7}$ by $\mathrm{H}$ abstraction.

\subsection{4 | Benzylic radical $/ \mathrm{O}_{2}$ manifold}

The detection of $\mathbf{1 8}$ implies the oxidation of a branched benzylic position, which is only possible through a sequence of events starting from the reaction of $\boldsymbol{\beta 8}$ with $\mathrm{O}_{2}$ to afford the peroxyl radical 及52, which dimerizes as tetroxide. Depending on conditions, the latter decomposes into $\boldsymbol{\beta 3 2}$ or/and $\boldsymbol{\beta 4 1}$ and $\boldsymbol{\beta 4 2}$. 332 decomposes into $\mathbf{1 2}$ and $\boldsymbol{\beta 3 3}$, which affords $\mathbf{2 5}$ by $\mathrm{H}$-abstraction. $\mathbf{1 8}$ is obtained in larger quantity in 3 than in 2, probably because of the four benzyl moieties in 3 .

Under gamma irradiation, $\boldsymbol{\beta 4 1}$ affords radical cations $\boldsymbol{\beta} 29$ and $\beta 53$. $\beta 42$ affords radical cations $\boldsymbol{\beta 3 0}, \boldsymbol{\beta 3 7}$, and $\boldsymbol{\beta 3 1}$. Radical cation $\boldsymbol{\beta 2 9}$ affords $\boldsymbol{\beta 3 5}$ through intramolecular $\mathrm{H}$-transfer and loss of proton via $\boldsymbol{\beta 5 0}$. Similarly, $\boldsymbol{\beta 5 3}$ affords $\boldsymbol{\beta} 35$ through intramolecular $\mathrm{H}$-transfer and loss of proton via $\boldsymbol{\beta 3 4}$. Radical $\boldsymbol{\beta 3 5}$ decomposes into 23 and $\boldsymbol{\beta 3 6}$, which decarbonylates to afford $\boldsymbol{\beta 2 8}$ yielding $\mathbf{1 8}$ by $\mathrm{H}$ abstraction. Radical cation $\boldsymbol{\beta 5 3}$ also decomposes into $\boldsymbol{\beta 2 8}$ (vide supra) and alkoxyacylium cation which yields $\mathbf{2 4}$ via hydrolysis and decarboxylation events. Radical cation $\boldsymbol{\beta 3 0}$ decomposes into $\mathbf{\beta 2 8}$ and alkoxyacylium cation. The latter is hydrolyzed in hydrogen carbonate, which collapses into $\mathrm{CO}_{2}$ and $\mathbf{2 4}$.

By intramolecular 1,4-H-atom transfer, radical cation $\boldsymbol{\beta} 37$ affords $\boldsymbol{\beta 3 8}$, which gives $\boldsymbol{\beta 3 9}$ by loss of a proton. $\boldsymbol{\beta 3 9}$ is readily oxidized in cation $\boldsymbol{\beta 4 0}$ by electron loss, and yields $\boldsymbol{\beta} 41$ by proton loss. On the other hand, $\boldsymbol{\beta 3 9}$ cleaves into radical $\boldsymbol{\beta 9}$ (see ester manifold in Scheme 9 for its reactivity) and in the enol form $\boldsymbol{\beta 5 1}$ of $\mathbf{1 8 .}$ 
T A B L E $4 \quad$ By-products of 4: Tris (2,4-di-tert-butylphenyl) phosphite $\gamma$-irradiated at $270 \mathrm{kGy}$ and subsequently dissolved in dichloromethane analyzed by GC-MS

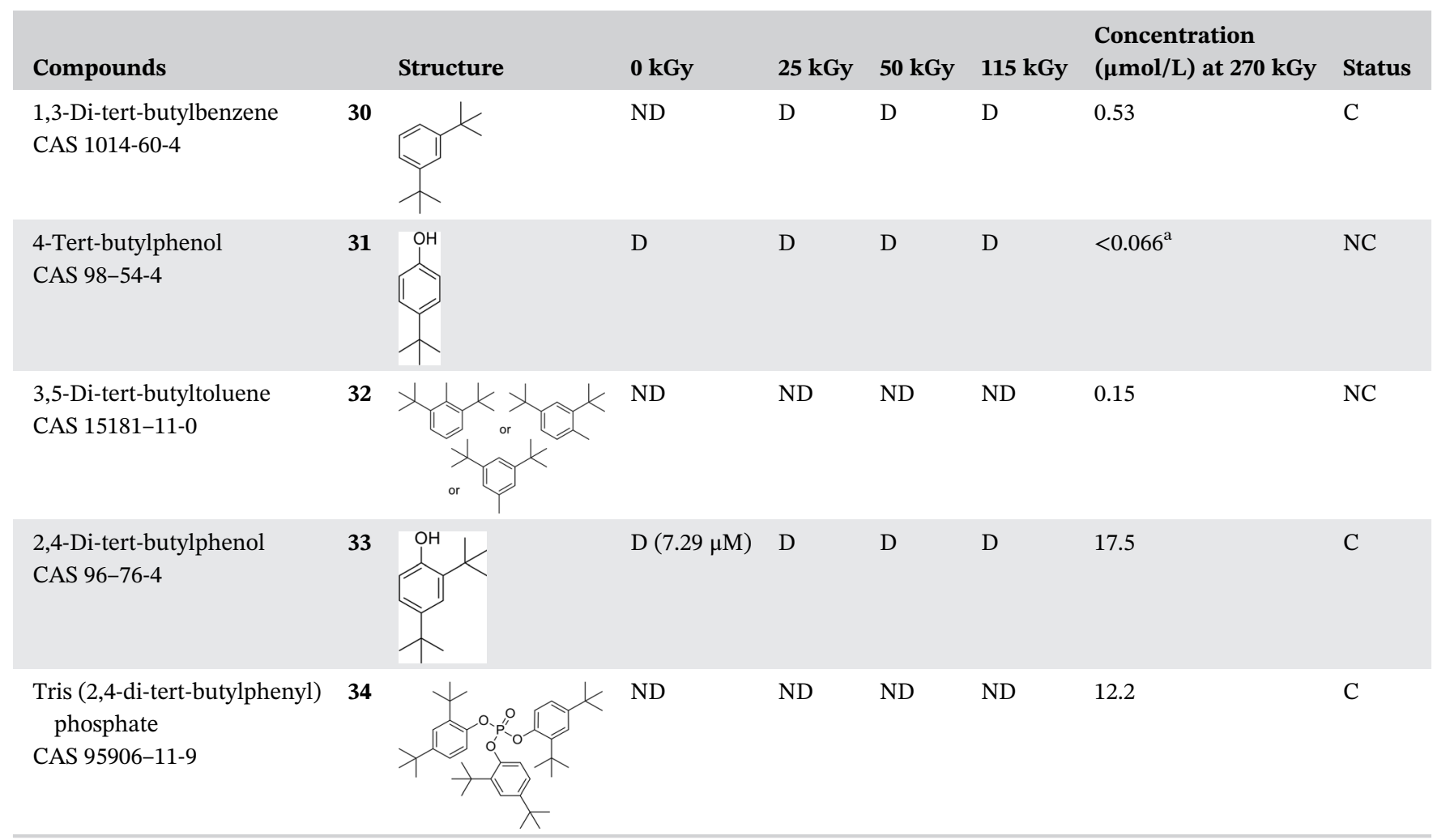

Note: The formations of $\mathbf{3 0},{ }^{[63-65]} \mathbf{3 2}, \mathbf{3 3 ^ { [ 6 3 - 6 6 ] }}$ and $\mathbf{3 4}$ are proposed in Scheme 18. The formation of $\mathbf{3 1}$ detected as traces is not discussed. Abbreviations: C, confirmed by standard; D, detected; NC, not confirmed by standard; ND, not detected.

${ }^{\text {a }}$ This reporting value corresponds to $\mathrm{S} / \mathrm{N} \sim 3$.

\subsection{5 | Acidic manifold}

The lactone ring $\mathbf{2 0}$ is obtained by 1,5-intramolecular cyclization via $\boldsymbol{\beta} 49$ starting from $\boldsymbol{\beta 2 5}$ (Scheme 12). At the same time, under gamma-irradiation, $\boldsymbol{\beta 2 5}$ generates $\boldsymbol{\beta 4 3}$ whose mesomeric form $\boldsymbol{\beta 4 4}$ cleaves in 7 and in alkyl radical $\boldsymbol{\beta 4 7}$, the latter being transformed into acetic acid $\boldsymbol{\beta} 48$ by $\mathrm{H}$-abstraction. $\boldsymbol{\beta 4 4}$ loses an $\mathrm{H}$-atom to yield $\boldsymbol{\beta 4 5}$. The ozonolysis of $\boldsymbol{\beta 4 5}$ into $\mathbf{1 6}$ is very unlikely, as no malonic derivative $\beta 46$ is detected. In contrast, ozonolysis of 7 yields 16. As re-aromatization is an important driving force, $\boldsymbol{\beta 4 5}$ is spontaneously isomerized into $\mathbf{2 9}$. Ozonolysis of the latter affords $\mathbf{1 2 .}$

\section{4 | By-products of 4 (tris (2,4-di-tert- butylphenyl) phosphite)}

When processing polyethylene, different chemical reactions occur, which modify the structure of the polymer. The overall kinetics of these reactions depends on the number of weak sites (branches, unsaturated, and oxygen-containing groups), the concentration of residual catalyst, and the processing conditions. The rate and direction of the reactions can be influenced by processing stabilizers, mainly involving a combination of hindered phenols and phosphorus-based secondary antioxidants. The decomposition of the hydroperoxide is assumed to be the main mechanism (Scheme 13) for the reactions of different trivalent phosphites and is accompanied by oxidation to the corresponding pentavalent compound. ${ }^{[0,72,73,75-79]}$ Scheme 16 is more likely than Scheme 15. The reaction of phosphites with peroxyl radicals formed in the autooxidation of organic compounds results in the formation of phosphates and alkoxyl radicals (Scheme 14), which further react with a second phosphite molecule in a way depending on the structures of the phosphorous compound and the alkoxyl radical. Phosphonites and alkyl phosphites are oxidized to the corresponding phosph(on)ates and alkyl radicals by alkoxyl radicals (Scheme 15). Thus, these phosphorous compounds are unable to act as chain-breaking antioxidants, at least at ambient temperature. However, the chain-breaking inability should not be the main reactional scheme. In contrast, hindered aryl phosphites can react with alkoxyl radicals by substitution reactions giving substituted alkylaryl phosphite derivatives and hindered aryloxyl radicals (Scheme 16), which terminates 
$\beta 1$<smiles>[R]OC(=O)CCc1cc(C(C)(C)C)c([O])c(C(C)(C)C)c1</smiles>

$\beta 4$<smiles>CC(=O)O[Na]</smiles>

$\beta 7$

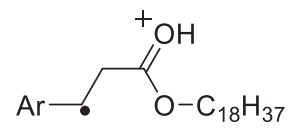<smiles></smiles>

$\beta 5$<smiles>[13CH3]OC(=[OH+])CC[Te]</smiles><smiles>[13CH2]=COC(=O)CC[13CH3]</smiles><smiles>[14CH3]COC(=[OH+])CC[Te]</smiles>

$\beta 11$

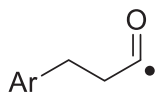

$\beta 19$<smiles>[17CH3]CCC([O])=O</smiles>

$\beta 22$

$$
\mathrm{C}_{18} \mathrm{H}_{37} \mathrm{O}^{\bullet}
$$

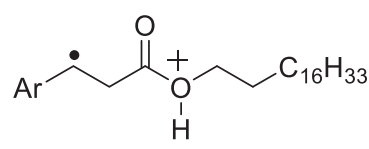<smiles>[13CH]C([O])OC(=O)CC[Al]</smiles>
$\beta 26$<smiles>[13CH3]C([18O])OC(=O)CC[Al]</smiles>
$\beta 27$ $\beta 3$<smiles>[R]OC(=O)/C=C/c1cc(C(C)(C)C)c(O)c(C(C)(C)C)c1</smiles>

$\beta 6$

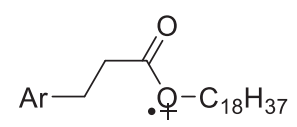

$\beta 9$<smiles>CC(=O)O[13CH3]</smiles>

$\beta 12$<smiles>[14CH3][14CH2][CH]OC(=O)CC[Al]</smiles>

$\beta 18$

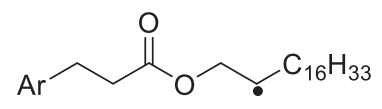

$\beta 21$<smiles></smiles>

$\beta 25$<smiles>CC(C)(C)c1cc(CCC(=O)O)cc(C(C)(C)C)c1O</smiles>

F I G U RE 2 List of intermediate compounds $\beta$

the oxidation chain reactions. Phosphite antioxidants are in most cases used in synergy ${ }^{[80]}$ with primary antioxidants such as 2 and 3.

The stabilizing action of phosphites could be therefore summarized by to three main mechanisms ${ }^{[74,81]}$ :

- Oxidation of the phosphorus compound by hydroperoxides transforms these compounds into alcohols and prevents the branching of the oxidation chain reaction (Scheme 13).

- Substitution of hindered aryl phosphites by alkoxyl radicals formed in the reaction of peroxyl radicals with the phosphites releases hindered aroxyl radicals that are capable of terminating the oxidation chain reaction (Schemes 14-16).

- Hydrolysis of aryl phosphites gives hydrogen phosphites and phenols 
$\beta 28$<smiles>CC(=O)Br</smiles>

$\beta 31$<smiles>[13CH3]C([18OH])CC(=O)O[18OH]</smiles>

$\beta 34$<smiles>CCCCCCCCCCCC(=[OH+])OCCCC(=O)Br</smiles>

$\beta 37$

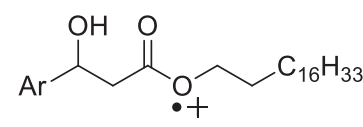
$\beta 40$

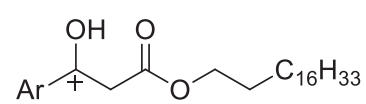

$\beta 43$<smiles>CC(C)(C)c1cc(CCC(=O)O)cc(C(C)(C)C)c1[O]</smiles>

$\beta 46$<smiles>O=C(O)CC(=O)O</smiles>

$\beta 49$<smiles>CC(C)(C)C1=CC(=CCC(=O)O)C=C(C(C)(C)C)C1=O</smiles>

$\beta 50$

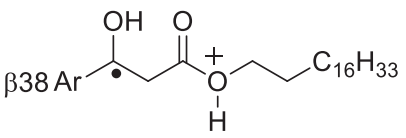
$\beta 41$<smiles>[R]OC(=O)CC(=O)Br</smiles>

$\beta 44$<smiles>CC(C)(C)c1cc(CCC(=O)O)cc(C(C)(C)C)c1</smiles>
$\beta 47$<smiles>CC(=O)O</smiles>

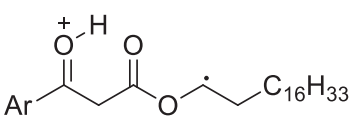
$\beta 51$<smiles>C=C(O)c1cc(C(C)(C)C)c(O)c(C(C)(C)C)c1</smiles>

$\beta 45$ $\beta 42$<smiles>[R]OC(=O)CC(O)Br</smiles><smiles>CC(C)(C)C1=CC(=CCC(=O)O)C=C(C(C)(C)C)C1=O</smiles>

$\beta 48$<smiles>CC(=O)O</smiles>

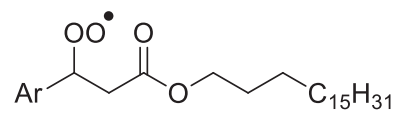

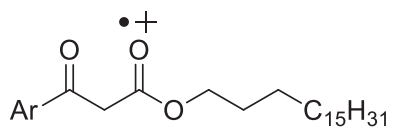

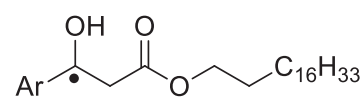

F I G URE 2 (Continued)

$\mathrm{P}(\mathrm{OAr})_{3}+\mathrm{ROOH} \longrightarrow \mathrm{O}=\mathrm{P}(\mathrm{OAr})_{3}+\mathrm{ROH}$

SCHEME 13 Decomposition of hydroperoxide with trivalent phosphites ${ }^{[72-74]}$

$\left.\mathrm{P}(\mathrm{OAr})_{3}+\mathrm{ROO} \longrightarrow \mathrm{ROO}-\dot{\mathrm{P}}(\mathrm{OAr})_{3} \longrightarrow \mathrm{RO}+\mathrm{O}=\mathrm{P}+\mathrm{OAr}\right)_{3}$

SCHEME 14 Reaction of phosphites with peroxylradicals ${ }^{[72,74]}$
$\left.\mathrm{P}(\mathrm{OAr})_{3}+\mathrm{RO}^{\cdot} \longrightarrow \mathrm{RO}^{\circ} \mathrm{P}+\mathrm{OAr}\right)_{3} \longrightarrow \mathrm{R}^{\cdot}+\mathrm{O}=\mathrm{P}-(\mathrm{OAr})_{3}$

SCHEME 15 Oxidation of phosphonites and alkyl phosphites ${ }^{[72,74]}$

$\mathrm{P}(\mathrm{OAr})_{3}+\mathrm{RO} \longrightarrow \mathrm{RO}-\mathrm{P}(\mathrm{OAr})_{2}+\mathrm{ArO}$

SCHEME 16 Reaction of hindered aryl phosphites with alkoxyl radicals ${ }^{[72,74]}$ 
The second part of the mechanism presented in Scheme 17 is proposed to account for the formation of bis (2,4-di-tert-butylphenyl)phosphate (bDtBPP). This compound $^{[82]}$ (Figure 3) was not detected in our study. Its GC-MS detection sensitivity is weak and may require concentration $>10 \mathrm{ppm}$ to be detectable.

The three mechanisms taking place in the core of the polymer therefore lead to the creation of new species either phosphorus or phenol based. These new species can remain stable over the life of the polymer or act with

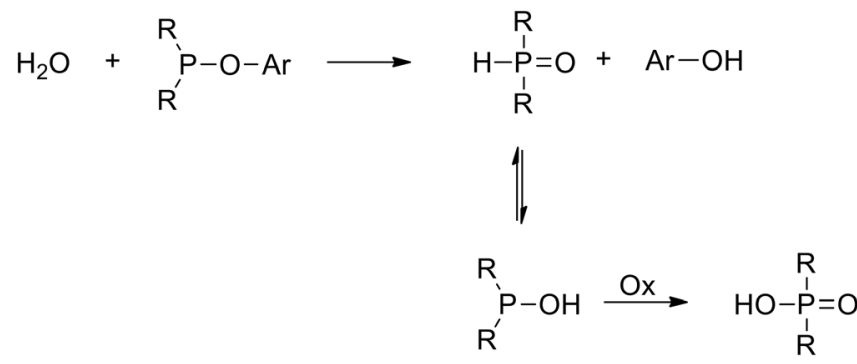

SCHEME 17 Hydrolysis of aryl phosphites

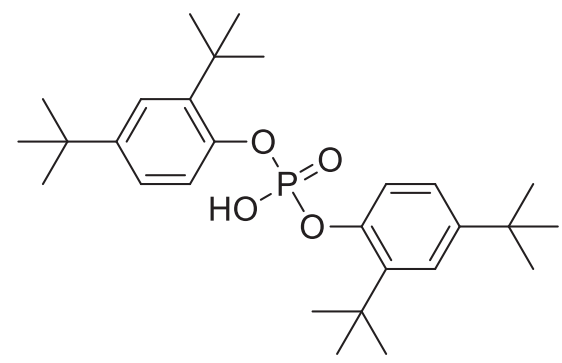

F I G U R E 3 Structure of bis(2,4-di-tert-butylphenyl) phosphate (bDtBPP) neighboring molecules to generate once again new species, thus involving complex chemistry.

Scheme 18 depicts the proposal of a mechanism for the degradation of the tris(2,4-di-tert-butylphenyl)phosphate, from the general processes described in Schemes 13-16.

Solutions of four $\gamma$-irradiated at $270 \mathrm{kGy}$ were prepared and analyzed by GC-MS. The detected compounds are summarized in Table 4. Information about detected compound masses is given in Table 4SI.

The highest concentration compounds $\mathbf{3 3}$ and $\mathbf{3 4}$ were also detected in film extracts directly while the other weakly concentrated compounds were not. ${ }^{[60,83]}$

\section{4 | CONCLUSIONS}

The purpose of this article is to highlight the degradation products we may expect from the radiative degradation of primary and secondary antioxidants and to address the complexity of the proper identification of the by-products thereof. A comprehensive profile of prone-to-migrate byproducts of the four antioxidants is thus established by analytical means and by degradation pathways. The degradation pathways reveal that numerous alkyl radicals are created, leading to the generation of numerous intermediates. Even though we were not able to detect the ESR signal of these radicals, the degradation pathways emphasize a possible radical reaction leading to the creation on the film surface of radicals which can then potentially generate hydro(gen) peroxides. This article summarizes probable degradation mechanisms of $\gamma$-irradiated antioxidants as key events to better apprehend the reactivity and the lifetime of intermediate radical species. We propose an
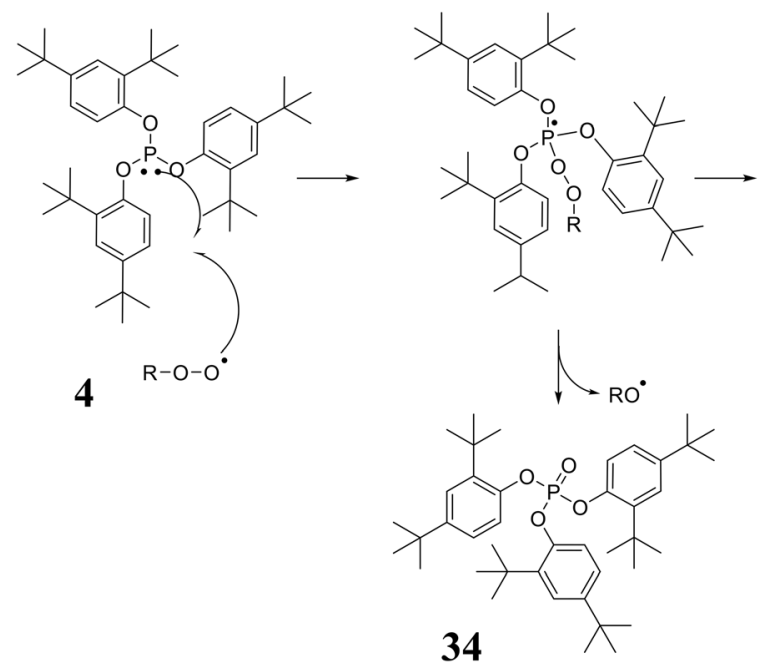
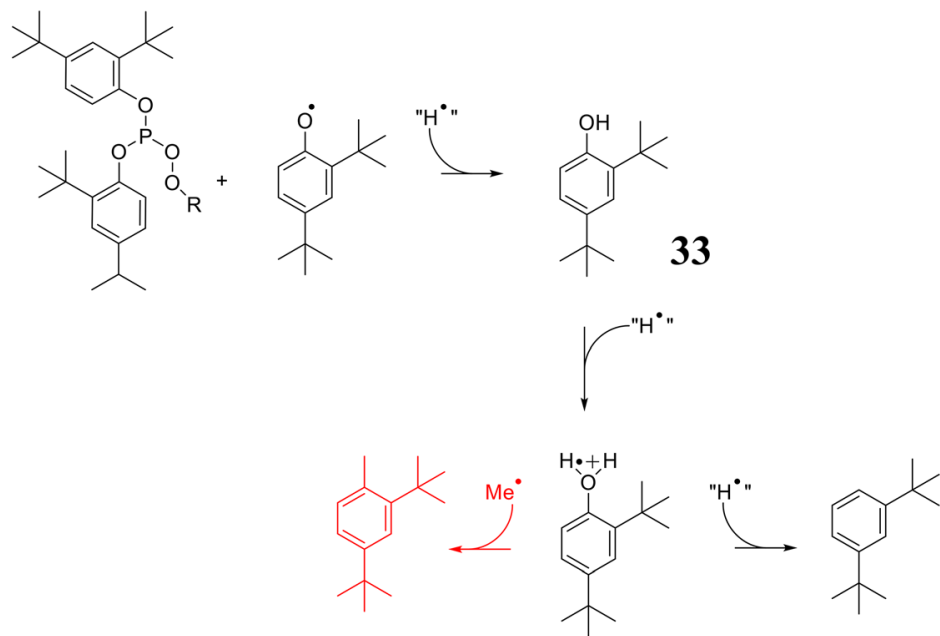

32

SCHEME 18 Degradation mechanism proposal leading to the formation of 1,3-di-tert-butylbenzene and of tris(2,4-di-tert-butylphenyl)phosphate [Color figure can be viewed at wileyonlinelibrary.com] 
identification of the chemicals compounds based either on the data fit to the commercial database, or by either on the injection of standards or on the antioxidant degradation chemistry. A deep investigation into the chemistry or more specifically into the phenolic antioxidant transformation mechanism behind the identification process is necessary to discriminate among several compounds to achieve trustworthy identification.

The chemistry of phenolic antioxidants emphasizes that the clear identification of the by-products from antioxidants remains a challenge, because of the many possible configurations one may find as improbable during extractable studies. It is worth noting that these byproducts are in really low quantity, surely below $100 \mu \mathrm{g} / \mathrm{L}$ and may be prone to migrate during biopharmaceutical applications. This study was performed on pristine antioxidants separate from the polymer matrix. The polymer matrix might bring another chemistry and hinder some of the reactions described in this paper. However, the data collected in this document could be used for further analysis and identification of compounds found in singleuse system extractable data sets and thus improve the robustness and relevancy of such extractable datasets.

\section{ACKNOWLEDGMENTS}

The authors acknowledge Sartorius Stedim FMT S.A.S. for the financial support of this work.

\section{ORCID}

Samuel Dorey (1D https://orcid.org/0000-0003-3178-2212 Nina Girard-Perier (i) https://orcid.org/0000-0002-5925668X

\section{REFERENCES}

[1] J. H. Bly, Modern Plastics Encyclopedia Handbook, McGrawHill Co., New York, NY 1994.

[2] A. L. Brody, K. S. Marsh, The Wiley Encyclopedia of Packaging Technology, Wiley, New York, NY 1997.

[3] J. Schmitz, BioPharm Int. 2014, 27, 27.

[4] Trotter, M.A. American Pharmaceutical Review (Ed: Mike Auerbach), Wayne, NewJersey 2012.

[5] European Commission. Good Manufacturing Practices, Medicinal Products for Human and Veterinary Use. http://ec. europa.eu/enterprise/pharmaceuticals/eudralex/homev4.htm (accessed: June 1998).

[6] US Food and Drug Administration. Current Good Manufacturing Practice for Finished Pharmaceuticals, Equipment Construction, 2013.

[7] Code of Federal Regulation (CFR). Title 21, Part 211.65 states: "Equipment shall be constructed so that surfaces that contact components, in-process materials, or drug products shall not be reactive, additive, or absorptive so as to alter the safety, identity, strength, quality, or purity of the drug product."

[8] FDA. Guidance for Industry: Preparation of Premarket Submissions for Food Contact Substances: Chemistry
Recommendations U.S. Department of Health and Human Services, Food and Drug Administration, Center for Food Safety and Applied Nutrition. https://www.fda.gov/Food/ GuidanceRegulation/GuidanceDocumentsRegulatoryInformation/ IngredientsAdditivesGRASPackaging/ucm081818.htm (2007).

[9] EU COMMISSION REGULATION No 10/2011. On plastic materials and articles intended to come into contact with food; Official Journal of the European Union. http://eur-lex.europa. eu/LexUriServ/LexUriServ.do?uri=OJ:L:2011:012:0001:0089: en:PDF (2011)

[10] M. Haji-Saeid, M. H. O. Sampa, A. G. Chmielewski, Radiat. Phys. Chem. 2007, 76, 1535.

[11] A. DePalma, Bioprocess Int. 2017, 15, 1.

[12] W. Ding, G. Madsen, E. Mahajan, S. O'Connor, K. Wong, Pharm. Eng. 2014, 34, 1.

[13] Product Quality Research Institute (PQRI). Thresholds and Best Practices for Leachables and Extractables in Parenteral and Ophtalmic Drug Produts Working group.

[14] ASME BPE. ASME BioProcessing Equipment. www.asme.org.

[15] ASTM. American Society for Testing and Materials. www. astm.org.

[16] USP. US Pharmacopeia. www.usp.org.

[17] UK Statutory Intrument No. 1401, Plastic Materials and Articles in Contact With Food Regulations, HMSE, London 1992.

[18] M. Hammond, H. Nunn, G. Rogers, H. Lee, A.-L. Marghitoiu, L. Perez, Y. Nashed-Samuel, C. Anderson, M. Vandiver, S. Kline, PDA J. Pharm. Sci. Technol. 2013, 67, 123.

[19] C. Sonnenschein, A. M. Soto, J. Steroid Biochem. Mol. Biol. 1998, 65, 143.

[20] T. T. Schug, A. Janesick, B. Blumberg, J. J. Heindel, J. Steroid Biochem. Mol. Biol. 2011, 127, 204.

[21] M. Adeel, X. Song, Y. Wang, D. Francis, Y. Yang, Environ. Int. 2017, 99, 107.

[22] H. J. Lim, E.-H. Lee, S.-D. Lee, Y. Yoon, A. Son, Chemosphere 2018, 211, 72.

[23] European Pharmacopeia. 3.1.5 and 3.1.7.

[24] I. Pahl, S. Dorey, M. Barbaroux, B. Lagrange, H. Frankl, PDA J. Pharm. Sci. Technol. 2014, 68, 456.

[25] Hemmerich, K.J. Medical Device and Diagnostic Industry. http://www.mddionline.com/article/polymer-materials-select ion-radiation-sterilized-products (2000).

[26] P. G. Demertzis, R. Franz, F. Welle, Packag. Technol. Sci. 1999, 12, 119.

[27] G. Audran, S. Dorey, N. Dupuy, F. Gaston, S. R. A. Marque, Polym. Degrad. Stabil. 2015, 122, 169.

[28] J. J. Killoran, Radiat. Res. Rev. 1972, 3, 369.

[29] J. C. M. Suarez, E. B. Mano, Polym. Degrad. Stabil. 2001, 72, 217.

[30] R. Buchalla, C. Schuttler, K. W. Bogl, J. Food Protect. 1993, 56, 998.

[31] R. Buchalla, C. Boess, K. W. Bögl, Radiat. Phys. Chem. 1999, $56,353$.

[32] L. Deschênes, A. Arbour, F. Brunet, M. A. Court, G. J. Doyon, J. Fortin, N. Rodrigue, Radiat. Phys. Chem. 1995, 46, 805.

[33] A. E. Goulas, M. G. Kontominas, Z Lebensm Unters Forch 1996, 202, 250.

[34] A. E. Goulas, A. Kokkinos, M. G. Kontominas, Z Lebensm Unters Forch 1995, 201, 74.

[35] A. E. Goulas, K. A. Riganakos, D. A. E. Ehilermann, P. G. Demertzis, M. G. Kontominas, J. Food Protect. 1998, 61, 720. 
[36] A. E. Goulas, K. A. Riganakos, A. Badeka, M. G. Kontominas, Food Addit. Contaminants 2002, 19, 1190.

[37] A. E. Goulas, K. A. Riganakos, M. G. Kontominas, Radiat. Phys. Chem. 2003, 68, 865.

[38] M. Driffield, E. L. Bradley, I. Leon, L. Lister, D. R. Speck, L. Castle, E. L. J. Potter, Food Addit. Contam. Part A Chem. Anal. Control Expo. Risk 2014, 31, 556.

[39] I. Vulic, G. Vitarelli, J. M. Zenner, Polym. Degrad. Stabil. 2002, 78, 27.

[40] P. P. Klemchuk, P.-L. Horng, Polym. Degrad. Stabil. 1991, 34, 333.

[41] C. P. de Oliveira, A. Rodriguez-Lafuente, N. D. F. F. Soares, C. Nerin, J. Chromatogr. A 2012, 1244, 61.

[42] N. H. Stoffers, J. P. H. Linssen, R. Franz, F. Welle, Radiat. Phys. Chem. 2004, 71, 205.

[43] J. Salafranca, I. Clemente, F. Isella, C. Nerín, O. Bosetti, Anal. Chim. Acta 2015, 878, 118.

[44] P. Vera, B. Uliaque, E. Canellas, A. Escudero, C. Nerín, Anal. Chim. Acta 2012, 745, 53.

[45] E. Canellas, P. Vera, C. Nerín, Food Chem. Toxicol. 2015, $75,79$.

[46] P. Vera, E. Canellas, C. Nerín, Food Chem. 2014, 145, 237.

[47] C. Nerin, In Reference Module in Food Science, Elsevier, Melbourne, Australia 2016.

[48] J. S. Félix, M. Monteiro, J. E. Manzoli, M. Padula, D. Pezo, J. Romero, C. Nerín, Anal. Bioanal. Chem. 2008, 391, 847.

[49] M. Funk, D. Schlettwein, U. Leist, Packag. Technol. Sci. 2016, 29, 289.

[50] K. Li, G. Rogers, Y. Nashed-Samuel, H. Lee, A. Mire-Sluis, B. Cherney, R. Forster, P. Yeh, I. Markovic, PDA J. Pharm. Sci. Technol. 2015, 69, 590.

[51] Green, J.R.; Schwarz, R.A.; Hillesland, K.E.; Roetman, V.E.; Field, J.G. Transportation and Packaging (Ed: Richard Levy), Westinghouse Hanford Company 1995.

[52] K. Vin, A. Connolly, T. McCaffrey, A. McKevitt, C. O'Mahony, M. Prieto, D. Tennant, A. Hearty, J. L. Volatier, Food Addit. Contam. Part A Chem. Anal. Control Expo. Risk 2013, 30, 2050.

[53] B. Nieva-Echevarría, M. J. Manzanos, E. Goicoechea, M. D. Guillén, Compr. Rev. Food Sci. Food Saf. 2015, 14, 67.

[54] G. M. Williams, M. J. Iatropoulos, J. Whysner, Food Chem. Toxicol. 1999, 37, 1027.

[55] S. Dorey, I. Pahl, I. Uettwiller, P. Priebe, A. Hauk, Ind. Eng. Chem. Res. 2018, 57, 7077.

[56] I. Pahl, S. Dorey, I. Uettwiller, C. Hoffmann, P. Priebe, R. Menzel, A. Hauk, Bioprocess Int. 2018, 21, 16.

[57] The Irradiation and Sterilization Subcommittee of the BioProcess Systems Alliance (BPSA). Guide to Irradiation and Sterilization Validation of Single-Use Bioprocess Systems. http:// www.bioprocessintl.com/upstream-processing/upstream-singleuse-technologies/guide-to-irradiation-and-sterilization-validationof-single-use-bioprocess-systems-183975/ 2008.

[58] D. Jenke, A. Odufu, Eur. J. Pharm. Sci 2006, 27, 133.

[59] D. Jenke, J. Castner, T. Egert, T. Feinberg, A. Hendricker, C. Houston, D. G. Hunt, M. Lynch, A. Shaw, K. Nicholas, D. L. Norwood, D. Paskiet, M. Ruberto, E. J. Smith, F. Holcomb, PDA J. Pharm. Sci. Technol. 2013, 67, 448.

[60] L. Marghitoiu, J. Liu, H. Lee, L. Perez, K. Fujimori, M. Ronk, M. R. Hammond, H. Nunn, A. Lower, G. Rogers, Y. NashedSamuel, PDA J. Pharm. Sci. Technol. 2015, 69, 49.
[61] T. R. Crompton, Additive Migration From Plastics into Foods: A Guide for Analytical Chemists, Smithers Rapra Technology Limited, Shrewsbury 2007.

[62] D. Jenke, Compatibility of Pharmaceutical Products and Contact Materials: Safety Considerations Associated with Extractables and Leachables, John Wiley, Hoboken, N.J 2009.

[63] D. Jenke, PDA J. Pharm. Sci. Technol. 2005, 59, 265.

[64] I. Kriston, G. Pénzes, G. Szijjártó, P. Szabó, P. Staniek, E. Földes, B. Pukánszky, Polym. Degrad. Stabil. 2010, 95, 1883.

[65] D. Jenke, S. Swanson, E. Edgcomb, PDA J. Pharm. Sci. Technol. 2005, 59, 360.

[66] F. Bourges, G. Bureau, B. Pascat, Packag. Technol. Sci. 1992, 5, 197.

[67] NIST, 2015

[68] Wiley database 9th Edition.

[69] Levin, R.D.; Lias, S.G. Ionization Potential and Appearance Potential Measurements, National Bureau of Standard, Washington DC, USA 1982.

[70] H. Zweifel, Stabilization of Polymeric Materials, Springer, Berlin, Heidelberg 1998.

[71] J. Pospíšil, Polym. Degrad. Stabil. 1993, 40, 217.

[72] K. Schwetlick, T. König, C. Rüger, J. Pionteck, W. D. Habicher, Polym. Degrad. Stabil. 1986, 15, 97.

[73] C. Neri, S. Costanzi, R. M. Riva, R. Farris, R. Colombo, Polym. Degrad. Stabil. 1995, 49, 65.

[74] K. Schwetlick, W. D. Habicher, in Polymer Durability (Eds: R. L. Clough, N. C. Billingham, K. T. Gillen), American Chemical Society, Washington, DC 1996, p. 349.

[75] G. Scott, Pure Appl. Chem. 1972, 30, 267.

[76] N. S. Allen, M. Edge, Fundamentals of Polymer Degradation and Stabilisation, Elsevier Applied Science, London 1992.

[77] C. Walling, R. Rabinowitz, J. Am. Chem. Soc. 1959, 81, 1243.

[78] W. O. Drake, K. D. Cooper, Proc. SPE Polyolefins 1993, 249, 414.

[79] D. J. Carlsson, M. E. Krzymien, L. Deschênes, M. Mercier, C. Vachon, Food Additiv. Contamin 2001, 18, 581.

[80] S. Al-Malaika, Polym. Degrad. Stabil. 1991, 34, 1.

[81] R. L. Clough, N. C. Billingham, K. T. Gillen, in Polymer durability: Degradation, stabilization, and lifetime prediction (Eds: R. L. Clough, N. C. Billingham, K. T. Gillen), American Chemical Society, Washington, D.C. 1996.

[82] M. Hammond, L. Marghitoiu, H. Lee, L. Perez, G. Rogers, Y. Nashed-Samuel, H. Nunn, S. Kline, Biotechnol. Prog. 2014, 30, 332.

[83] C. Ta, J. Bones, J. Chromatogr. A 2017, 1492, 49.

\section{SUPPORTING INFORMATION}

Additional supporting information may be found online in the Supporting Information section at the end of this article. 